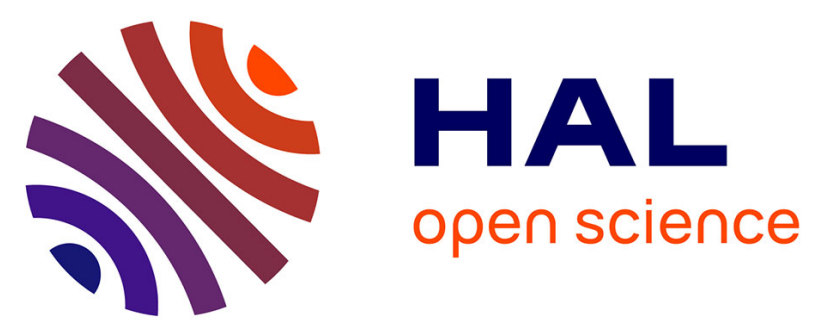

\title{
A 7000-year environmental history and soil erosion record inferred from the deep sediments of Lake Pavin (Massif Central, France)
}

Léo Chassiot, Yannick Miras, Emmanuel Chapron, Anne-Lise Develle, Fabien Arnaud, Mikael Motelica-Heino, Christian Di Giovanni

\section{To cite this version:}

Léo Chassiot, Yannick Miras, Emmanuel Chapron, Anne-Lise Develle, Fabien Arnaud, et al.. A 7000year environmental history and soil erosion record inferred from the deep sediments of Lake Pavin (Massif Central, France). Palaeogeography, Palaeoclimatology, Palaeoecology, 2018, 497, pp.218-233. 10.1016/j.palaeo.2018.02.024 . insu-01719229

\section{HAL Id: insu-01719229 \\ https://hal-insu.archives-ouvertes.fr/insu-01719229}

Submitted on 28 Feb 2018

HAL is a multi-disciplinary open access archive for the deposit and dissemination of scientific research documents, whether they are published or not. The documents may come from teaching and research institutions in France or abroad, or from public or private research centers.
L'archive ouverte pluridisciplinaire HAL, est destinée au dépôt et à la diffusion de documents scientifiques de niveau recherche, publiés ou non, émanant des établissements d'enseignement et de recherche français ou étrangers, des laboratoires publics ou privés. 


\section{Accepted Manuscript}

A 7000-year environmental history and soil erosion record inferred from the deep sediments of Lake Pavin (Massif Central, France)

Léo Chassiot, Yannick Miras, Emmanuel Chapron, Anne-Lise Develle, Fabien Arnaud, Mikaël Motelica-Heino, Christian Di

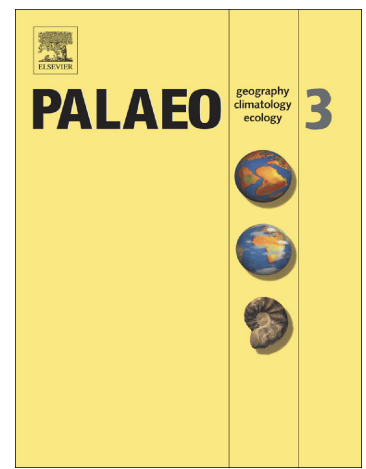
Giovanni

PII: $\quad$ S0031-0182(17)30695-8

DOI: $\quad$ doi:10.1016/j.palaeo.2018.02.024

Reference: $\quad$ PALAEO 8682

To appear in: $\quad$ Palaeogeography, Palaeoclimatology, Palaeoecology

Received date: $\quad 26$ June 2017

Revised date: $\quad 19$ February 2018

Accepted date: $\quad 24$ February 2018

Please cite this article as: Léo Chassiot, Yannick Miras, Emmanuel Chapron, Anne-Lise Develle, Fabien Arnaud, Mikaël Motelica-Heino, Christian Di Giovanni , A 7000-year environmental history and soil erosion record inferred from the deep sediments of Lake Pavin (Massif Central, France). The address for the corresponding author was captured as affiliation for all authors. Please check if appropriate. Palaeo(2017), doi:10.1016/ j.palaeo.2018.02.024

This is a PDF file of an unedited manuscript that has been accepted for publication. As a service to our customers we are providing this early version of the manuscript. The manuscript will undergo copyediting, typesetting, and review of the resulting proof before it is published in its final form. Please note that during the production process errors may be discovered which could affect the content, and all legal disclaimers that apply to the journal pertain. 


\section{A 7,000-year environmental history and soil erosion record}

\section{inferred from the deep sediments of Lake Pavin (Massif Central,}

\section{France)}

Léo Chassiot ${ }^{\mathrm{a}, *}$, Yannick Miras ${ }^{\mathrm{b}, \mathrm{c}}$, Emmanuel Chapron ${ }^{\mathrm{a}, \mathrm{d}}$, Anne-Lise Develle ${ }^{\mathrm{e}}$, Fabien Arnaud $^{\mathrm{e}}$, Mikaël Motelica-Heino ${ }^{\text {a }}$, Christian Di Giovanni ${ }^{\text {a }}$

a Institut des Sciences de la Terre d'Orléans (ISTO), UMR 7327, CNRS, Université d'Orléans, BRGM, 1A, rue de la Férollerie, 45071 Orléans Cedex 2, France.

b GEOLAB, UMR 6042, CNRS, Université Clermont-Auvergne, F-63000 Clermont-Ferrand, France.

${ }^{\text {c } H i s t o i r e ~ N a t u r e l l e ~ d e ~ 1 ' H o m m e ~ P r e ́ h i s t o r i q u e ~(H N H P), ~ U M R ~ 7194, ~ C N R S, ~ D e ́ p a r t e m e n t ~ d e ~}$ Préhistoire, Muséum National d'Histoire Naturelle, Institut de Paléontologie Humaine, 1, rue René Panhard, 75013 Paris, France.

${ }^{\mathrm{d}}$ Géographie de l'Environnement (GEODE), UMR 5602, CNRS, Université Toulouse 2 Jean Jaurès, Allée A. Machado, 31058 Toulouse Cedex, France.

e Environnements, Dynamiques et Territoires de la Montagne (EDYTEM), UMR 5204, CNRS, Université Savoie Mont-Blanc, Bâtiment «Pôle Montagne », 73376 Le Bourget du Lac Cedex, France.

* to whom the correspondence should be addressed: leo.chassiot@ete.inrs.ca; Centre Eau Terre Environnement (ETE), Institut National de la Recherche Scientifique (INRS), 490 rue de la Couronne, Quebec City (Québec), G1K 9A9, Canada. 


\section{Abstract}

A 14-m long sedimentary sequence (core PAV12) was collected in the deepest part of Lake Pavin, a maar lake located in the French Massif Central. The PAV12 sedimentary sequence documents the lake's environmental evolution since its formation 7,000 years ago. The relationships between the catchment's vegetation cover, erosion processes and changes in trophic status were shown using a multi-proxy characterization of mineral and organic fractions supported by palynological data. The record shows a succession of lithological units starting at the base, with volcanoclastic material corresponding to the early stage of Lake Pavin. The deposition of organic-rich and diatomaceous sedimentary units above volcanoclastic material indicates an evolution toward a pristine lacustrine state. The Late Holocene environmental history of this lake is marked by two tipping points reflecting major environmental disturbances at ca. 4000 cal BP and after the deposition of erosive masswasting deposits (MWDs) at $1350 \mathrm{cal} \mathrm{BP}(\mathrm{AD} 600)$ and $650 \mathrm{cal} \mathrm{BP}(\mathrm{AD} 1300)$. The upper unit of core PAV12, which corresponds to the past 700 years, indicates that one of these MWDs was likely the driving force behind a major limnological change marked by a shift in redox-sensitive elements (i.e., current meromictic lacustrine state). The palynological diagram indicates a forested catchment where woodland clearances and agro-pastoral activities have remained limited except over the last 700 years. These findings suggest restricted human impact within the watershed compared to other regional archives. The reconstruction of the Lake Pavin erosion record determined from titanium and red amorphous particle fluxes highlights phases of enhanced erosion at ca. 6.5-5.5, 4.1-3.8, 3.5, 2.8-2.6, 1.6-1.4 cal kyr BP and during the Little Ice Age (LIA). A comparison between this erosion record, palaeoenvironmental archives from Western Europe and palaeoclimatic data supports an Atlantic signal driving precipitation patterns over Lake Pavin at centennial to millennial timescales. The influence of local human activities, even on a small scale, cannot be 
completely discounted as their impact on erosional processes may be amplified in a steep catchment such as that found in Lake Pavin.

\section{Keywords}

Maar lake; meromictic lake; paleolimnology; Holocene; NAO; human impact

\section{Introduction}

Maar lake sediments can provide high-resolution records of landscape evolution under human and/or climate influence. Therefore, they are considered key-sites for palaeoenvironmental studies over the Holocene and beyond (e.g., Brauer et al., 1999, Ariztegui et al., 2001, Martin-Puertas et al., 2012, Striewski et al., 2013, Zolitschka et al., 2013, Bhattacharya et al., 2015, Marchetto et al., 2015). Two decades ago, maar lake sediments in the French Massif Central were studied to reconstruct environmental changes. This was done using magnetic properties (Thouveny et al., 1990), organic and inorganic geochemistry (Truze and Kelts, 1993, Sifeddine et al., 1996) and palynology (Coûteau, 1984, Juvigné and Stach-Czerniak, 1998). However, many of these maars were formed during the last glacial period and their relatively low sedimentation rates allow for long-term climatic reconstructions over the last Glacial and Interglacial cycles.

Located in the Mont-Dore area, Lake Pavin differs from other regional maar lakes because of its steep catchment and anoxic and meromictic water column which has been intensively studied in recent decades (e.g., Meybeck et al., 1975, Martin et al., 1992, Michard et al., 1994, Viollier et al., 1995, 1997, Aeschbach-Hertig et al., 1999, 2002, Olive and Boulègue, 2004, Lehours et al., 2005, 2007, Assayag et al., 2008, Bura-Nakic et al., 2009, Bonhomme et al., 2011, Busigny et al., 2014, Cosmidis et al., 2014, Gal et al., 2015). By comparison, palaeoenvironmental investigations remain sparse with only two studies documenting the vegetation history and paleolimnology over the last 700 years (Stebich et al., 
2005, Schettler et al., 2007). In 2012, one long-piston core (PAV12) was collected in the deep central basin of Lake Pavin. The sedimentary sequence, previously described in Chassiot et al. (2016a, 2016b), displays a $14 \mathrm{~m}$ thick deposit of which $7 \mathrm{~m}$ are related to a background sedimentation dominated by diatoms. This high-resolution sequence allowed the lake's environmental and aquatic evolution to be documented since its formation ca. 7,000 years ago (Juvigné et al., 1996). Its steep catchment morphology differs from other regional paleoenvironmental records where landscapes have been strongly affected by human activities since the Neolithic (e.g., Guenet and Reille, 1988, Gay and Macaire, 1999, Miras et al., 2004, Lavrieux et al., 2013, Miras et al., 2015). Therefore, Lake Pavin sediments constitute a key paleoenvironmental archive within this region.

This study uses the PAV12 sequence to reconstruct the 7,000-yr environmental history of Lake Pavin. It focuses on the relationships between the vegetation cover and the organic and minerogenic terrigenous fluxes to identify the driving forces between Holocene climatic variability and human impacts. To do this, we used a multi-proxy approach by gathering published data on X-ray Fluorescence (XRF) conducted using a non-destructive core scanner and bulk organic geochemistry (Rock-Eval) (Chassiot et al., 2016a). We also provided new data, including Laser Ablation Inductively Coupled Plasma Mass Spectrometry (LA-ICP-MS) analyses, quantitative organic petrography (i.e., palynofacies) and palynological analyses. The chronological framework also reused radiocarbon data published in Chassiot et al. (2016a) to perform a new age-depth model based on a Bayesian Analysis (Blaauw and Christen, 2011).

\section{Settings}

\subsection{Geographical and geomorphological setting}

Lake Pavin is a $92 \mathrm{~m}$ deep maar lake located in the Mont-Dore area (Massif Central, France) at an elevation of $1197 \mathrm{~m}$ a.s.l. (Fig. 1A). Its diameter is about $750 \mathrm{~m}$ with an area of 
$0.44 \mathrm{~km}^{2}$ (Fig. 1B). Its bowl shape originates from a phreato-magmatic eruption that occurred ca. 7000 years ago (Juvigné et al., 1996). The volcanic fallout, mainly consisting of basaltic fragments and trachy-andesitic pumices, created a crater rim that encompasses the Montchal stratovolcano. This has marked out a steep and small topographic catchment area $\left(0.36 \mathrm{~km}^{2}\right)$ that is now covered by a dense forest, mainly composed of beech (Fagus sylvatica) and fir (Abies alba), and planted areas that are mainly composed of spruce (Picea abies) (Stebich et al., 2005, Fig. 1C). Water inputs are essentially due to precipitation along with inflows coming from subaerial and subaquatic springs located all around the crater rim and at the foot of the Montchal stratovolcano. The outflow goes north through an outlet and reaches the Couze Pavin, a tributary of the Allier River belonging to the Loire drainage basin (Fig. 1A). The meteorological station located in Besse-et-Saint-Anastaise (5 km east of Lake Pavin) records a mean average temperature near zero degrees during the winter months that causes the lake surface to freeze (partially or completely) during this period (Stebich et al., 2005). At the same location, annual precipitation (rain and/or snow) varies from 1200 to $1600 \mathrm{~mm} . \mathrm{yr}^{-1}$ (Meybeck et al., 1975, Stebich et al., 2005).

\subsection{Limnology}

Nowadays, Lake Pavin waters are permanently stratified, with an upper oxygenated, seasonally mixed water layer (i.e., mixolimnion) and a permanent anoxic and sulfidic water layer below $60 \mathrm{~m}$ depth (i.e., monimolimnion) (Fig. 2). In the last twenty years, numerous vertical profiles of physico-chemical parameters have been conducted on the water column (Michard et al., 1994, Viollier et al., 1995, 1997, Aeschbach-Hertig et al., 1999, 2002, Olive and Boulègue, 2004, Assayag et al., 2008), highlighting a strong vertical physico-chemical gradient between 60 and $70 \mathrm{~m}$ water depth (i.e., mesolimnion). Below this limit, enrichment in dissolved constituents (phosphorus, iron, manganese, arsenic, molybdenum and other redox-sensitive trace elements) increases water density, thus, favoring the stability of the 
bottom water (Viollier et al., 1995, Assayag et al., 2008). The lake's water balance between inflows and outflows shows a deficit. This suggests the existence of gas-rich groundwater inputs (Aeschbach-Hertig et al., 1999, Olive and Boulègue, 2004, Assayag et al., 2008) (Fig.

2) that contribute to maintaining the current meromixis (Bonhomme et al., 2011). According to hydrological equilibrium models and in-situ measurements, two subsurface springs have been inferred at $45 \mathrm{~m}$ and $90 \mathrm{~m}$ water depth, respectively (Viollier et al., 1997, AeschbachHertig et al., 2002, Assayag et al., 2008). The physical and chemical properties of the Lake Pavin water column enhance many biochemical and hydrological processes, illustrated in Fig. 2. Within the monimolimnion, the decay of particulate organic carbon (POC) is catalyzed by anoxic microbial communities, mainly bacteria and archaea, to favor methanogenesis (MET) by acetate fermentation pathway. The resulting $\mathrm{CH}_{4}$ goes upward and is progressively converted into $\mathrm{CO}_{2}$ by anoxic methane oxidation (AMO) via archaea (Lehours et al., 2005, 2007). Iron and phosphorous cycles remain tightly coupled with an enrichment of dissolved species in the deep waters following an "iron-wheel" process (Busigny et al., 2014, 2016).

\subsection{Sedimentary environments}

Geophysical mapping techniques, including multibeam swath bathymetry and hydroacoustic surveys, have already been used to illustrate the geometry of sedimentary deposits across the lake (Fig. 2) (Chapron et al., 2010, 2012, Chassiot et al., 2016a, 2016b). The results show the presence of a flat and circular basin surrounded by steep slopes that are incised by numerous canyons. Unfortunately, the gas-rich sediments in the deep basin do not allow acoustic signals to penetrate. However, a freeze-core retrieved in 2001 by a German team (core FC01) (Fig. 1B) shows an accumulation of annually laminated diatomaceous sediment (i.e., varves, e.g., Zolitschka et al., 2015) in the first two meters below the lake floor (Stebich et al., 2005, Schettler et al., 2007). In addition, core PAV12 displays 14 meters of sediments that can be divided into the following four main units: (1) an upper diatomaceous unit (0 - 207 
cm); (2) a mass-wasting deposit (MWD, 207 - $628 \mathrm{~cm})$; (3) a lower diatomaceous unit (628 $1045 \mathrm{~cm})$; and (4) a basal unit (1045 - $1400 \mathrm{~cm})$ made of laminated volcanoclastic materials interbedded with turbidites. A detailed description of these units is provided in Chassiot et al. (2016b).

The combination of hydro-acoustic images and sedimentary cores collected in three sedimentary environments (i.e., the littoral, the plateau and the deep basin) have allowed two major sedimentary events to be identified: (1) a 9 m lake-level fall following a crater outburst with a large subaquatic slump deposit on the plateau in ca. AD 600 (Chassiot et al., 2016b); and (2) an earthquake-triggered slope failure at the edge of the plateau in ca. AD 1300 (Chassiot et al., 2016c) (Fig. 2).

\section{Materials and methods}

\subsection{Sampling}

A continuous sequence was collected from the central part of the deep anoxic basin (92 m water depth) (Fig. 1B) using an UWITEC coring platform and 2-m long PVC tube sections. In the catchment, soil profiles were sampled under both deciduous and coniferous forests (Fig. 1B). PAV12 core sections were split for visual descriptions followed by nondestructive analyses before sampling. The sampling strategy was designed to focus on diatomaceous units (upper and lower units) corresponding to background sedimentation and the upper part of the basal unit documenting the early stage of Lake Pavin.

\subsection{Chronology}

The chronology of core PAV12 was established using radiocarbon dating performed on leaf debris in addition to a chronological framework established from previous studies (Table 1) (Schettler et al., 2007, Chapron et al., 2010, 2012, Chassiot et al., 2016a, 2016b). 
Because the intercalated MWD is erosive (Chassiot et al., 2016b), independent age-depth models were constructed for both the upper and lower diatomaceous units. For the upper unit, we combined two ages that were obtained using AMS radiocarbon dating performed on the leaf debris sampled in core PAV12 and in the nearby gravity core PAV09-B1 (Fig. 1B) (Chapron et al., 2012, Chassiot et al., 2016a), The AMS dates were in agreement with the calendar age obtained by varve counting on the nearby freeze-core FC01 (Schettler et al., 2007). In addition, the age of the deepest varve in FC01 (i.e., $668 \mathrm{cal} \mathrm{BP}$ ) was extrapolated to the base of the upper unit of core PAV12 (see Chassiot et al., 2016b for details). For the lower unit, we used the results obtained from AMS radiocarbon dating on eight leaf fragments sampled in core PAV12 and one from a bulk sediment sampled at the base of core PAV08 (Table 1) (Chapron et al., 2010). For the latter, we assumed a synchronous onset of diatomaceous sedimentation across Lake Pavin (Chassiot et al., 2016a, 2016b) and a negligible reservoir effect at the early stage of the lake (Albéric et al., 2013).

The BACON code package was used to perform age-depth modelling using Bayesian statistics (Blaauw and Christen, 2011) with the IntCal13 calibration curve (Reimer et al., 2013). The age-depth model was built using the weighted mean age for each depth. Within the lower unit, an interpolation was made between 645 and $1045 \mathrm{~cm}$ and an extrapolation from 645 to $628 \mathrm{~cm}$ to recover the complete sequence. Prior information included values of 1.5 for the accumulation shape, $10 \mathrm{yr} \cdot \mathrm{cm}^{-1}$ for the accumulation mean and $5 \mathrm{~cm}$ for the section thicknesses. Similar information was used for the age-depth model of the upper unit unless the accumulation mean adjusted to $5 \mathrm{yr} . \mathrm{cm}^{-1}$. The model settings were slightly adjusted to match the accurate varve chronology as much as possible. The radiocarbon age $220 \pm 30 \mathrm{BP}$ displaying a radiocarbon plateau was thus converted to a calendar age of $288 \pm 20$ cal BP (likelihood of 37\%, Chassiot et al., 2016b), in agreement with the varve age at this depth.

\subsection{Multi-proxy analyses}




\subsubsection{Inorganic geochemistry}

Basal, lower and upper sedimentary units were analyzed using an Avaatech ${ }^{\mathrm{TM}} \mathrm{XRF}$ core scanner with a Rhodium tube source. The settings were adjusted to $10 \mathrm{kV}$ and $0.75 \mathrm{~mA}$ with an acquisition time of 20 seconds to measure the relative intensities of light elements (Al to $\mathrm{Fe})$. A second run was performed for heavier elements $(\mathrm{Cu}$ to $\mathrm{Pb})$ after adjusting the settings to $30 \mathrm{kV}, 0.5 \mathrm{~mA}$ and 30 seconds, respectively. Principal Component Analyses (PCA) were then performed on selected XRF data (Al, Si, Ca, Ti, Mn, Fe, Br, Rb, Sr, Zr and $\mathrm{Pb}$ ) using the FactoMineR package (Lê et al., 2008). In addition, tablets of crushed sediment $(n=23)$ were prepared for LA-ICP-MS analyses that were performed following the procedure described in Gratuze et al. (2001). The aim was to calibrate the semi-quantitative XRF signal by sampling the core at regular intervals and to quantify trace elements that cannot be assessed using the core scanner.

\subsubsection{Organic geochemistry}

On soil $(n=7)$ and sediment $(n=69)$ samples, bulk organic geochemistry analyses were conducted using RE pyrolysis, a technique that characterizes organic matter composition by thermal cracking through multiple parameters (Behar et al., 2001). Among them, Total Organic Carbon (\% TOC) and Hydrogen Index (HI = S2/TOC in mg.HC.gTOC $\left.{ }^{-1}\right)$ are widely used to characterize soil organic matter (e.g., Di Giovanni et al., 1998, 2000, Disnar et al., 2003, Sebag et al., 2006a) and to assess the preservation and/or the origin of lacustrine organic matter (algal vs. terrestrial inputs, Ariztegui et al., 2001, Simonneau et al., 2013, 2014).

\subsubsection{Quantitative organic petrography}

On the same set of samples, thin sections were prepared for quantitative organic petrography (i.e. palynofacies) using a microscope (Graz et al., 2010). During the process, 1 
$\mathrm{cm}^{3}$ of wet sediment was sampled and then dried at $40^{\circ} \mathrm{C}$ for a week to measure the dry bulk density. Carbonate and silicate fractions were removed after the addition of hydrochloridric and hydrofluoridric acids. A pollen standard (Cupressus sp.) was added to the solution before the preparation of thin sections. Organic compounds were then quantified and classified according to their color (transparent yellowish to dark brown reddish), their shape (amorphous vs. figured), and their texture (gelified, granular or flocky) (e.g., Sifeddine et al., 1996, Di Giovanni et al., 1998, 2000, Sebag et al., 2006b, Simonneau et al., 2013, 2014).

\subsubsection{Terrigenous fluxes}

The semi-quantitative signal from XRF coupled to LA-ICP-MS analyses allows the quantification of an elemental terrigenous tracer: titanium (Ti expressed in \%). On the other hand, quantitative organic petrography allows the quantification of organic terrigenous particles such as red Amorphous Particles (rAP expressed in mg.g ${ }^{-1}$ ) (e.g., Sebag et al., 2006b, Simonneau et al., 2013, 2014). Both results were transformed into fluxes expressed in $\mathrm{mg} . \mathrm{cm}^{-}$ ${ }^{2} \cdot \mathrm{yr}^{-1}$ using the dry bulk density $\left(\mathrm{g} . \mathrm{cm}^{-3}\right)$ and the sedimentation rate $\left(\mathrm{cm} \cdot \mathrm{yr}^{-1}\right)$.

\subsubsection{Palynology}

Samples for palynological analyses $(\mathrm{n}=100)$ were prepared using the standard procedures (Faegri and Iversen, 1989). Pollen and Non-Pollen-Palynomorphs (NPP) counts were undertaken using a microscope at a magnification of $\mathrm{x} 500$. The section between 781 and $830 \mathrm{~cm}$ depth has yet not been analyzed. Average counts of 500 pollen grains per sample from terrestrial plants were obtained. Pollen and NPP values were calculated as the percentage of total pollen excluding Cyperaceae, fern spores and aquatic plants. Pollen and spores were identified with the aid of Reille (1992), whereas different published illustrations were used for the NPP identification (e.g. van Geel et al., 2003 and Cugny et al., 2010 for the fungal spores, and Sweeney, 2004 for the stomata). Summary curves gather pollen taxa according to their 
ecological affinity in Auvergne (Antonetti et al., 2006) and pollen and NPP (Coprophilous fungi) taxa according to their indicative value in relation to anthropogenic impact (Table 2) (Behre, 1981, Ejarque et al., 2011, Miras, 2009, Baker et al., 2013). These summary results are expressed in percentages obtained with the same pollen sum as the total diagram, except for the Coprophilous fungi summary curve, which is expressed in part per thousand. The palynological diagram was plotted using the C2 program (Juggins, 1991) and Pollen Assemblage Zones (PAZ) were established using PAST with Euclidian similarity measure (Hammer et al., 2001).

\section{Results}

\subsection{Age-depth model}

Independent age-depth models for upper and lower units are compiled in Fig. 3. The lower unit documents the period between 7 and 1.5 cal kyr BP, whereas the upper unit covers the last 700 years. The MWD, dated ca. AD 1300 (Chassiot et al., 2016b, 2016c), thus, eroded ca. 800 years of former sediments. Within the lower unit, only one radiocarbon sample was rejected from the model and the $95 \%$ confidence interval never exceeds 264 years with a mean of 180. This unit displays small fluctuations in the sedimentation rate, starting from 0.75 mm. $\mathrm{yr}^{-1}$ at the early stage of Lake Pavin to over $1 \mathrm{~mm} \cdot \mathrm{yr}^{-1}$ after 2.7 cal kyr BP. The sedimentation rate then increases to $3.5 \mathrm{~mm} \mathrm{yr}^{-1}$ in the upper unit. Within this unit, the $95 \%$ confidence interval reaches a maximum of 87 years with a mean of 63 . The comparison between our radiocarbon chronology and the varve chronology of Schettler et al. (2007) indicates a maximum offset of 70 years. The main differences between these two models represent slight changes in the sedimentation rate that cannot be inferred from our radiocarbon dataset. Finally, the presence of three leaf fragments with an offset of 1,000 years in the upper unit is likely a consequence of storage in soils or sediments before erosion, transport and 
sedimentation at the core site. In Lake Pavin, this can be explained by the remobilization of former leaf debris stored in littoral deposits that had emerged following the lake-level fall in AD 600 (Chassiot et al., 2016a).

\subsection{Minerogenic signal}

Geochemical measurements performed on wet sediments using an XRF core scanner showed an interrupted record of mineral fractions (Fig. 4A). A few sediment sections located at the base of the upper unit and at the top of the lower unit could not be scanned due to an elevated water content and the fluffy texture of diatomaceous units (Tjallingi et al., 2007). For the same reason, the lighter elements, $\mathrm{Al}$ and $\mathrm{Si}$, may not have been accurately measured and will not be considered hereafter (Tjallingi et al., 2007, Croudace and Rothwell, 2015). The behavior of the element distribution within the lower and the upper units was assessed with PCAs (Fig. 4B). For the lower unit, more than $75 \%$ of the variance is explained by the F1axis, where the elements $\mathrm{K}, \mathrm{Ca}, \mathrm{Ti}, \mathrm{Fe}, \mathrm{Mn}, \mathrm{Rb}, \mathrm{Sr}$ and $\mathrm{Zr}$ gather to form a "detrital endmember". In the upper unit; however, the results indicate two major poles, with $\mathrm{K}, \mathrm{Ca}, \mathrm{Ti}$, $\mathrm{Rb}$, Sr and $\mathrm{Zr}$ characterizing the detrital one, whereas Fe and Mn diverge to form a "redox endmember". One remarkable feature along core PAV12 is the dramatic rise in Fe and As content within the upper unit. In the anoxic waters of Lake Pavin, elevated values of such redox-sensitive elements likely represent an artefact related to the precipitation of dissolved species in pore-water soon after the core opening (i.e., oxidation of ferrous oxide into ferric oxide). However, this behavior was observed for the upper unit only, suggesting the lower unit was depleted of iron-rich pore-water where the PCA indicates Fe and Mn have a behavior similar to other detrital elements (Fig. 4B).

The assessment of terrigenous minerogenic supplies at Lake Pavin was done using titanium (Ti) because (1) this element is globally unaffected by biogeochemical processes inside the water column (Löwemark et al., 2011); and (2) it constitutes a good detrital 
indicator for Lake Pavin as its highest values are recorded in the basal unit made of volcanoclastic material. There is a significant positive relationship between the semiquantitative XRF signal of Ti and the quantitative signal obtained by LA-ICP-MS (Fig. 4C, $r$ $=0.90 ; \mathrm{p}<0.0001)$. Differences between the two signals are explained by the fluffy surface of the diatomaceous units that is inadequate for precise quantification with X-ray beams. Moreover, both the elevated water content and the high organic fraction strongly affect element quantification (i.e., the closed-sum effect) (Tjallingi et al., 2007, Weltje and Tjallingi, 2008, Löwemark et al., 2011).

\subsection{Organic signal}

The organic signal of PAV12 indicates elevated and fluctuating TOC values, less than $3 \%$ in the basal unit, between 6 and $18 \%$ in the lower unit, and between 5 and $8 \%$ in the upper unit (Fig. 5A). The S2/TOC plot also highlights the main organic signatures for forested soils and lacustrine sediments. Soil samples illustrate a high variability in TOC content (i.e., $1 \%$ for the deepest horizons to $18 \%$ for the litters) but their hydrogen content, expressed via the Hydrogen Index $(\mathrm{HI}=\mathrm{S} 2 / \mathrm{TOC})$, remains low and constant around $300 \mathrm{mgHC} \cdot \mathrm{gTOC}^{-1}$. This signature is typical of terrestrial domain (Disnar et al., 2003, Sebag et al., 2006a). Conversely, the organic matter signature from the lower unit is more variable, showing an intermediate HI distribution between the algal pole $\left(\mathrm{HI}=750 \mathrm{mgHC} \cdot \mathrm{gTOC}^{-1}\right)$ and the terrestrial one $(\mathrm{HI}=300$ mgHC.gTOC ${ }^{-1}$ ), whereas the upper unit displays lower S2 values.

In addition to the Rock-Eval pyrolysis, quantitative organic petrography revealed a high diversity of organic compounds from various sources (Fig. 5B). Amorphous particles and ligno-cellulosic particles comprise the overwhelming majority of the observations (> 95\%). Among them, amorphous organic particles (AOM) display a yellow to grey color with an amorphous irregular shape and a granular to flocky texture. They have only been identified 
in lake sediments and are therefore, attributed to the primary productivity in the water column (Sebag et al., 2006b, Simonneau et al. 2013, 2014). Red amorphous particles (rAP) display a dark reddish color and a gelified texture without internal structure. Ligno-cellulosic fragments (LCF) have been recognized by their elongated form, where internal vesicles can be visible according to their degree of maturity reflected by a color gradient from transparent yellowish to gelified dark brownish. LCF and rAP have been identified in both lake sediments and soil layers (litter and horizon A). Thus, their occurrence in lake sediments represents terrestrial inputs via runoff within the catchment (e.g., Sebag et al., 2006b, Simonneau et al. 2013, 2014). Other palynomorphs, such as fungi mycelium (MYC), have also been quantified in low amounts and will not be discussed hereafter (Fig. 5B).

\subsection{Palynology}

\subsubsection{PAZ Pav-1 (1260 - $983 \mathrm{~cm}, \mathrm{ca} 6900-6050 \mathrm{cal} \mathrm{BP})$}

Mean Arboreal Pollen (AP) values $\geq 95 \%$ characterize the PAZ Pav-1 (Fig. 6A). Quercus (oak, with values that increase from 32 to 40\%), Corylus (hazelnut, with frequencies that increase from 21 to 30\%), Tilia (lime, ca. 7\%) and Ulmus (elm, ca 7\%) are predominant within the arboreal types. This assemblage indicates the reginal presence of a diversified forest. The arboreal types also include heliophilous trees such as Pinus (pine, up to 11\%) these frequencies are associated with one occurrence of Pinus stomata -, Betula (birch, up to 7.6\%) and riparian trees like Fraxinus (ash, up to 15\%), Alnus (alder, up to 7\%) and Salix (willow, ca $0.9 \%$ ). This may reflect the noticeable presence of wooded areas within the catchment. At the end of the zone, occurrences of Fagus and Abies near 2\% were observed which may indicate the onset of their regional extension. The herbaceous pollen component dominated by Poaceae and Pteridophytes (monolete spores, ca 4\%, and trilete spores, ca 1\%) suggests open areas also existed at different spatial scales. 
4.5.2. PAZ Pav-2 (977 - $933 \mathrm{~cm}, \mathrm{ca} 6000$ - $5200 \mathrm{cal} \mathrm{BP})$

This zone is mainly defined by a decreasing trend in Quercus (down to 20\%) and Corylus (down to 10\%) values. However, there is also a change in the Tilia, Ulmus, Fraxinus and Betula frequencies, which decrease below 5\% (Fig. 6A). Conversely, the percentages of Fagus (up to 33\%) and Abies (up to 43\%) substantially increased. This suggests a reorganization of the forest cover implying an extension of the mountain woodland at both regional and local scales. In this sense, high frequencies of Abies are associated with regular occurrences of Abies stomata. The decrease in Poaceae and Pteridophyte (mainly monolete spores) values (down to $2 \%$ ) also argues in favor of a denser forested landscape in the area of the lake than in the previous zone. Despite this, the higher taxonomic diversity among the non-arboreal pollen (NAP) assemblage may suggest that some open areas remained present within this forest development.

\subsubsection{PAZ Pav-3 (880 - $844 \mathrm{~cm}, \mathrm{ca} 4380-3880 \mathrm{cal} \mathrm{BP})$}

The dominant feature of this zone (Fig. 6A) is the appreciable decrease in the Fagus (from $44 \%$ to $25 \%$ ) and Abies (down to $12 \%$ ) frequencies. Conversely, the values of other arboreal types show an increasing trend, specifically Quercus (up to 27\%) and Corylus (up to 12.6\%). This slight retraction of the mountain woodland may have resulted in a moderate opening of the landscape which would explain a higher regional pollen input from Quercus and Corylus. This pollen evidence is concomitant with the first record of Cerealia-pollen type at 913 and $917 \mathrm{~cm}$ depth and to an overall increase in the values of different anthropogenic pollen indicators (API) (e.g. Mercurialis annua-type, Plantago lanceolata, Rumex, Rumex acetosella-type, Artemisia) as well as Poaceae (up to 2,7\%). These pollen data may be ascribed to the development of human activities in the Lake Pavin area between ca 5000 and 4600 cal BP. The regular occurrences of Abies and Pinus stomata suggest that the catchment area remained forested during this period. Moreover, the higher frequencies of Alnus and 
Betula compared to those of the previous PAZ (up to 5\%) indicate an extension of the riparian vegetation in the lake's surroundings.

\subsubsection{PAZ Pav-4 (838 - $752 \mathrm{~cm}, \mathrm{ca} 4380$ - $2640 \mathrm{cal} \mathrm{BP})$}

The abundance of Fagus and Abies pollen, with values up to 50 and $35 \%$ respectively, is characteristic of the PAZ Pav-4 (Fig. 6A). The frequencies of other arboreal taxa, such as Quercus (mean values around 20\%) and Corylus (mean values around 10\%), are stable and substantial. This indicates that the landscape within the catchment and around the maar was well wooded. In this sense, the frequencies of the riparian vegetation tree taxa remained globally stable. This general pattern is mainly interrupted by two noticeable declines in the Fagus frequencies which indicate two retraction phases of the beech woodlands. These features explain why the PAZ Pav-4 was divided in two sub-zones (Fig. 6B).

In the PAZ Pav-4a, between ca 4100 and $3850 \mathrm{cal} \mathrm{BP} \mathrm{(862} \mathrm{and} 844 \mathrm{~cm}$ depth), the percentages of Fagus decreased appreciably from 45 to 30\% (Fig. 6A). Abies values remained stable at around $18 \%$ while Abies stomata present a noticeable increasing trend during this period. At the same time, the small increase in the Poaceae frequencies (up to 3.7\%) corroborates this episode of woodland opening, which may be human-induced. In this sense, the regular occurrences of Cerealia pollen-type as well as the values of Plantago sp, Rumex, and Artemisia suggest a human impact. The substantial amount of Abies stomata (up to $0.3 \%$ ) may be explained by an enhanced erosion within the catchment, possibly linked to these human activities. The coeval record of Diporotheca rhizophila fungal spores (ca $0.17 \%$ ), a good indicator of soil disturbance (Hillbrand et al., 2012), in addition to an increased amount of trampling pollen indicators, supports these interpretations.

The second event is observed in the PAZ Pav-4b between ca 3000 and 2550 cal BP (781 and $744 \mathrm{~cm}$ depth) and presents more or less similar trends to the first one: (1) a 
substantial drop in Fagus percentages (from ca 51 to 31\%) accompanied by an important rise in Abies frequencies (from 12 to $30 \%$ ). This can be explained by a favored pollen representation of this taxon and the clearance of beech woodland near Lake Pavin (de Beaulieu et al., 1982); (2) one occurrence of Cerealia pollen-type and mean Poaceae values around 3\%; (3) a regular record of API (mainly Plantago sp, Plantago lanceolata, Rumex, Artemisa, Chenopodiaceae); and (4) an increased observation of Pinus and Abies stomata (ca $2 \%)$. Sporormiella fungal spores were observed for the first time around $3000 \mathrm{cal} \mathrm{BP}(781 \mathrm{~cm}$ depth). All these findings could indicate that some agricultural activities and woodland openings may have taken place in the lake area.

\subsubsection{PAZ Pav-5 (748 - $627 \mathrm{~cm}, \mathrm{ca} 2600$ - $1450 \mathrm{cal} \mathrm{BP})$}

The PAZ Pav-5 is divided in two sub-zones (Fig. 6B). The first part of the zone (PAZ5a) is mainly defined by the renewal of all woodlands (Fig. 6A). This is reflected by an increasing trend in the frequencies of Fagus (up to 52\%), Quercus (up to 22\%) and heliophilous and riparian trees (with mean Betula and Alnus values around 8\%). The Abies values are moderate, at around $15 \%$. Open areas are scattered within this forested landscape, as evidenced by a higher number of herbaceous taxa, mainly Poaceae, with values that rise to ca $5 \%$.

Two phases of woodland regression were identified in the second part of the zone (PAZ Pav-5b) (Fig. 6A). The first one was dated between approximately 2400 and 2050 cal BP (721 and $687 \mathrm{~cm}$ depth). Here, Fagus percentages decline from 51 to $40 \%$ and Abies values gradually decrease to $7 \%$. Conversely, the Quercus frequencies increase to $22 \%$, which suggests a higher regional pollen input. It is not easy to connect this event with the impact of human activity since API are scarce. Nevertheless, the occurrences of Polygonum aviculare, Urticaceae and a noticeable record of Plantago sp and Rumex (ca 1.3\%), suggests the possible development of regional human activities. 
A more palpable episode of human activities responsible for limited woodland clearances in the area of the maar was detected between ca 1950 and 1500 cal BP (677 and $627 \mathrm{~cm}$ depth). The decrease in Fagus was moderate (down to 44\%) and accompanied again by a rise in the Abies percentages (up to $18 \%$ ). The regular occurrences of Cerealia pollentype (ca $0.4 \%$ ) and Secale-type (rye, $0.3 \%$ ) indicate that some cereal cultivation took place near the maar. The rising trend of ruderals, trampling indicators (Plantago sp, Plantago lanceolata) and other apophytes (Rumex, Chenopodiaceae, Artemisia) also provide evidence for grazing activity.

\subsubsection{PAZ Pav-6 (202 - $35 \mathrm{~cm}, \mathrm{ca} 640$ - $35 \mathrm{cal} \mathrm{BP})$}

The PAZ Pav-6 is divided in two sub-zones. The opening of the PAZ Pav-6a is marked by a decrease in the AP/NAP ratio from ca 93 to $66 \%$. This is mainly explained by the gradual decrease in the Fagus frequencies (down to 20\%), the stability of the Abies percentages at low values (around 5\%) and the substantially higher number of herbaceous pollen taxa such as Poaceae (up to 16\%). An increase in taxonomic diversity was also concomitantly observed. For example, there were regular occurrences of Caryophyllaceae, Rosaceae, Scrophulariaceae, and Ranunculaceae; the zone was characterized by Ericaceae and Calluna curves; Cerealia-type and Secale-type pollen were more abundant (up to 5\% for Secale-type values) and fungal spores from coprophilous fungi Sporormiella and Coniochaeta cf Ligniaria were observed. Taken together, these data may indicate that the regional landscape became more open despite the persistence of some woodland patches within the catchment, as indicated by the record of tree taxa stomata and relatively high residual Fagus frequencies. The riparian vegetation located in the lakeshore is also concerned (Betula and Alnus values around 8\%). The increase in grasses, herbaceous taxa, and Pteridophytes suggest the expansion of open areas and grazed pastures in the vicinity of Lake Pavin where anthropogenic activities also included cereal cultivation. A new surge in woodland clearance 
related to the extension of agro-pastoral activity is highlighted subsequent to 500 cal $\mathrm{BP}$ (above $174 \mathrm{~cm}$ depth). A higher regional input explains the slight increase in the Quercus frequencies (from 14 to $20 \%$ ).

The main feature of the onset of PAZ Pav-6b is indicated by a rise in the values of all arboreal types: Fagus (up to 28\%), Abies (up to 16\%) and Quercus (up to 27\%). The frequencies of heliophilous trees such as Pinus, Betula and Corylus remain stable at significant percentages (around 5\%). A higher amount of Pinus stomata was also recorded. Tree taxa composing riparian vegetation (mainly Alnus and Salix) also showed increased values. Conversely, the abundance of Poaceae and other herbaceous taxa decreased in the pollen assemblage (below $10 \%$ for Poaceae). The various API showed an overall tendency to decline, such as Cerealia-type and Secale-type or apophytes, ruderals and trampling indicators like Rumex, Plantago sp, Artemisia. Thus, this period between 240 and 180 cal BP (107 - 87 $\mathrm{cm}$ depth) is characterized by the regeneration of a forested landscape within the catchment and more regionally in the maar area. This event may be explained by reduced anthropogenic pressure and/or agro-pastoral activities developed at a fair distance from the lake. Subsequently, and until the end of the PAZ dated to the end of the XIX ${ }^{\text {th }}$ century, the opening of the landscape at both the local and regional scales is indicated by the lowest values in the AP/NAP pollen ratio (down to 70\%). This is synchronous with the expansion of pastured grasslands (increasing trend of Poaceae values up to 13\%, apophytes and grazing pollen indicators like Rumex, Plantago sp, Plantago lanceolata, and coprophilous fungi with regular observations of Sporormiella). Appreciable Secale-type frequencies (up to 5\%), associated with regular observations of arable weeds (Centaurea cyanus), suggest that arable fields may have expanded in the areas surrounding the maar. The regular occurrence of Fagopyrum (buckwheat), substantial values of Cannabis-Humulus pollen-type (up to 5\%) and planted 
trees such as Castanea (chestnut) and Juglans (walnut) indicate a diversification of the landuse system developed in this upland.

\subsubsection{PAZ Pav-7 (25 - $1 \mathrm{~cm}$, sub-recent period)}

The frequencies of the main tree taxa present an oscillating pattern in the last PAZ Pav-7. This is mainly related to important variations of the AP/NAP ratio (from 82 to 58 and then $70 \%$ ). A new surge in beech woodland clearance is indicated by the decrease in Fagus, with a decrease in frequency to $11 \%$. This explains a higher amount of pollen from tree taxa developed both at regional and local scales (respectively Quercus, Abies and Pinus). Increased agro-pastoral exploitation of these upland areas characterizes this zone and includes: rye (Secale-t: 6.2\%) and hemp (Cannabis-Humulus-t: 2.5\%) cultures and grazing activities in more extended grasslands and meadows (maximal values of Poaceae around 20\%, increasing trend of different API and coprophilous fungi such as Sporormiella and Sordaria). A significant break in this trajectory is noticeable at the end of the zone reported to the $\mathrm{XX}^{\text {th }}$ century. Pollen data indicate a slow decrease in all agro-pastoral indicators. This is associated with progressive reforestation (renewal of Fagus percentages toward 21\%).

\section{Discussion}

\subsection{Lake Pavin paleolimnology and environmental history}

\subsubsection{Stage I (7000 - 6500 cal BP)}

The volcanoclastic sediments described in the basal unit of core PAV12 reflect the early stage of Lake Pavin, which settled in the crater as a mineral maar lake shortly after the volcano's eruption ca. 7,000 years ago. The matching of this date with the onset of diatomaceous sedimentation, dated at $6940 \pm 90$ cal BP at the core PAV08 site (i.e., a subaquatic plateau currently at $48 \mathrm{~m}$ water depth) suggests rapid filling. Applying the modern hydrological budget presented in Assayag et al. (2008) confirms this theory. The total water 
input of $50 \mathrm{~L} . \mathrm{s}^{-1}$ implies a filling time inferior to 15 years to reach the present-day water volume (i.e., $23.10^{6} \mathrm{~m}^{3}$ ). Such a rapid lake-level rise and/or intense rain events on a poorly vegetated catchment likely triggered slope failures, recorded as turbidite sequences in the basal unit (Chassiot et al., 2016a).

From 7 to $6.5 \mathrm{cal} \mathrm{kyr} \mathrm{BP}$, the decrease in the mineral fraction, coupled with a rise in the organic fraction, indicates a transition from a mineral lake to an organic lake dominated by the sedimentation of diatoms and organic matter (Fig. 7). During this period, pollen and stomata data provide evidence for the local presence of pine in the catchment and the existence of riparian vegetation on the lakeshore despite the fact that deciduous oak woodland was regionally dominant (Reille et al., 1985, Miras et al., 2015). The growing vegetation on the bare catchment promoted soil formation and therefore, reduced its erodability. Thus, the Ti content decreased to a baseline of approximately $0.1 \%$, as did the dry bulk density, which reached $0.35{\mathrm{~g} . \mathrm{cm}^{-3}}^{-}$. Conversely, the TOC content increased from 2 to $7 \%$ while the primary production throughout the water column is illustrated by a rapid rise in HI and AOM content contributing to the onset of organic-rich sediments. Finally, the small amount of rAP indicates soil inputs, implying either a rapid pedogenesis process on the Pavin volcanic fallout, or a transfer from soils developed on the flanks of the Montchal volcano, whose northern side is part of the Pavin catchment area (Fig. 1C).

\subsubsection{Stage II $(6500-1500$ cal BP $)$}

The next stage is marked by the onset of organic-rich sediments, illustrated by hydrogen-rich organic matter with TOC values between 10 and $18 \%$ and low dry-bulk densities between 0.25 and 0.5 g.cm ${ }^{-3}$ (Fig. 7). The increase in the HI index, between 500 and 600 mg.HC.g.TOC ${ }^{-1}$, is in agreement with the quantification of algal markers, where low/high HI periods match low/high AOM content. Elevated proportions of rAP correspond to periods of reduced $\mathrm{HI}$ content and therefore, underline the role of terrestrial inputs in the dilution of 
the authigenic signal. Numerous Ti peaks were also observed, including one sharp peak dated 4.0 - 3.8 cal kyr BP. Both rAP and Ti reflect erosion processes along the crater's steep slopes, where numerous gullies and thalwegs have been identified within the dense forest (Chapron et al., 2010, Chassiot et al., 2016b). Throughout this period, we distinguished three phases labelled IIa, IIb and IIc in Fig. 7 and which are described below.

The first phase (IIa) spans from 6.5 to $3.8 \mathrm{cal} \mathrm{kyr} \mathrm{BP}$ and shows an increase from 7 to $10 \%$ in TOC content. Mountain woodland (Table 2), mainly composed of beech and fir, progressively replaced diversified oak woodland (Table 2) and started its maximal extension between ca 5.4 and 5.1 cal kyr BP. This agrees with the pollen record from Lake Aydat (Fig. 1) nearby (Miras et al., 2015). This type of evolution is a common feature in several pollen records from Western Europe and is associated with the onset of the Neoglacial era (Magny and Haas, 2004), with colder and wetter conditions conducive to large vegetation changes in mountain areas. During this phase, palynological data reveal a number of human-induced landscape changes in the maar's vicinity. These include episodic forest openings and smallscale and non-permanent agricultural practices, notably between ca 5 - 4.6 cal kyr BP and ca 4.1 - $3.85 \mathrm{cal}$ kyr BP. On the basis of the pollen data; however, it remains difficult to precisely locate these human activities within or outside the catchment area. Thus, it is difficult to assess the possible anthropogenic contribution to the erosion processes. Nevertheless, it may be suggested for the second phase especially because: (1) the intensity of the pollen frequency fluctuations are substantial, reflecting an appreciable regression of the mountain woodlands; (2) all of the forested vegetation groups seem to be affected by these changes, including the riparian vegetation present on the lakeshore; (3) the high recurrence of arable farming, grazing and trampling indicators suggest more intense and repeated human activity; and (4) the recurrence of different indicators that are mainly transported by run-off, including some possible indicators of soil erosion. Finally, a similar and coetaneous event has been previously 
described in the nearby lake Aydat and for which anthropogenic drivers have also been addressed (Lavrieux et al., 2013).

The next phase (IIb) starts soon after the record of the major Ti input and ends at 3.2 cal kyr BP. This phase is marked by a regression of the dry bulk density values and an increase in the AOM and TOC contents. Consequently, the 4 cal kyr BP detrital input should be seen as a tipping point in Lake Pavin's environmental history, producing an irreversible impact on its limnology (e.g., Brisset et al., 2013).

The last phase of zone II (IIc), between 3.2 to 1.5 cal kyr BP, shows a slight rise in the sedimentation rate over $1 \mathrm{~mm} . \mathrm{yr}^{-1}$. A progressive decline in TOC content was also recorded during this period, with the exception of a peak at $2.8 \mathrm{cal}$ kyr BP where organic signals reflect a terrigenous input (i.e., low HI coeval to an elevated amount of rAP and LCF). During this phase, the elevated rAP values suggest that the terrigenous inputs were mainly of organic origin (Fig. 7) while the palynological data indicates concomitant episodes of woodland regression and/or grazing activities within the catchment area (Figs. 6A and 7).

\subsubsection{Stage III (700 cal BP - today)}

The last 700 years constitute the final stage in the evolution of Lake Pavin's limnology (Fig. 7). During this period, the sediments show a general drop in HI and TOC values. This has been attributed to an abrupt environmental change (i.e., lake-level drop) associated with the deposition of two MWDs (Fig. 2) (Chassiot et al., 2016a). The upper unit is also characterized by a noticeable shift in redox-sensitive elements (Fig. 4). Because this shift occurred after the deposition of two large MWDs, it is acceptable to infer that either the AD 600 crater outburst and/or the AD 1300 slope failure may have played a key role in the onset of the "iron-wheel" process in Lake Pavin (Fig. 2) (Michard et al., 1994, Viollier et al., 1995, Cosmidis et al., 2014, Busigny et al., 2016). However, a downward diffusion of trace 
elements within the upper unit and/or a remobilization of authigenic minerals during diagenesis cannot be excluded (Tribovillard et al., 2006 and references therein). The reconstruction of paleo-redox conditions; however, is beyond the scope of this article. In this aim, ongoing investigations using biotic and abiotic proxies will complement the paleolimnological characterization and past evolution of Lake Pavin's trophic status.

The last seven centuries document runoff processes with two detrital phases underlined by Ti peaks at 450 - 250 and 180 - 90 cal BP. This latter phase is also synchronous with elevated amounts of rAP (Fig. 7). Although, the PAV12 detrital record is in agreement with the FC01 record, where Schettler et al. (2007) described an increase in erosion between 300 and $50 \mathrm{cal} \mathrm{BP}$, the 70-year offset between both records prevents any further comparison.

\subsection{Climatic and anthropic impacts on the Lake Pavin erosion record.}

The Lake Pavin erosion record, combining the rAP and Ti fluxes, reflects the joint influence of hydroclimatic fluctuations and human disturbances on the erosion processes affecting the catchment. At Lake Pavin's elevation, the increase in terrigenous markers could result from spring rain, snowmelt (Tanasienko et al., 2011) or rain-on-snow events during the winter (Beniston and Stoffel, 2016). An anthropogenic contribution is also possible since some of these phases of increased terrestrial inputs are coincident with evidence of human impact on vegetation. Simonneau et al. (2013) recently compared rAP and Ti signals in the sedimentary record of Lake Paladru (French Alps) and suggested that Ti reflects more intense agricultural activities due to the remobilization of deeper soil horizons by ploughing. Lake Pavin's catchment has a peculiar configuration, with steep inner slopes that prevent farming. This supports the assumption that human influences on the erosion processes in this catchment were more moderate than in other lakes in Auvergne (e.g. Lake Aydat, Lavrieux et al., 2013). On the other hand, one cannot exclude the possibility that even at a low magnitude, 
these steep slopes may have augmented the impact of forest clearance, cattle breeding and/or grazing activities on the erosion processes.

In the next sections, comparisons were made between the Lake Pavin erosion record (Ti and rAP fluxes), palynological data, selected paleoenvironmental archives from Western Europe and paleoclimatic (solar and oceanic) proxies to disentangle the respective roles of humans vs. climate over the last 700 years (Fig. 8) and during the mid to late Holocene (Fig. 9).

\subsubsection{The last 700 years}

Ti flux records two detrital phases at 450 - 250 cal BP (ca AD 1500 - 1700) and 180 90 cal BP (ca AD 1770 - 1860) (Fig. 8). These phases correspond to periods of intensified human activities revealed by palynological data in the surroundings of Lake Pavin, where the landscape is appreciably more open. There is evidence for crop fields and grazed pasturelands starting at $640 \mathrm{cal} \mathrm{BP}$ (Fig. 7). The periods between 500 and $240 \mathrm{cal} \mathrm{BP}$, and between $180 \mathrm{BP}$ and the present are characterized by reduced woodland cover. This corresponds with previous research that found a minimum of beech woodlands during the XVI ${ }^{\text {th }}$ and the XVII ${ }^{\text {th }}$ centuries (Stebich et al., 2005). Nevertheless, it is important to mention that, according to our pollen data, some wooded areas probably remained present within the catchment during historical times. This fact constitutes an important peculiarity of Lake Pavin in comparison with other lakes located in Auvergne. Finally, it must be mentioned that these two phases of increased human impact, which are coincident with the Ti peaks, are separated by a phase of reduced anthropogenic pressure and the renewal of forests between ca 240 and 180 BP (ca AD 1710 1765). The period between AD 1670 and 1830 was also previously characterized by variable beech pollen values "possibly affected by unsettled climatic conditions" (Stebich et al., 2005). 
In detail, the Lake Pavin erosion record displays eight short-term Ti peaks, five of which match a flood occurrence in the Lake Aydat sedimentary record during the XVII ${ }^{\text {th }}$ century and in AD 1780 and 1850 (Lavrieux et al., 2013). The timing of most of these detrital phases also corresponds with a succession of cold decades during the XVII ${ }^{\text {th }}$ century described in a summer temperature reconstruction from the Alps (Büntgen et al., 2006). The erosion record also matches several patterns relative to North Atlantic climatic indexes, including negative phases of the Atlantic Multidecadal Oscillation (AMO, Mann et al., 2009) and the North Atlantic Oscillation (NAO) (Fig. 8) (Ortega et al., 2015). In Western Europe, the westerlies blowing from the North Atlantic Ocean condition the moisture distribution and most of the precipitation patterns (Mayewski et al., 2004), where the negative NAO phases enhance wetter winters and snowfall. The AMO, related to 65-80-year cycles in Sea Surface Temperatures (SST) over the North Atlantic Ocean, can disturb climatic patterns over Europe via air temperature anomalies in the Northern Hemisphere (Alexander et al., 2014). The Little Ice Age (LIA), which corresponds to the last glacial advance documented in Europe, is characterized by cold and wet climatic conditions across the Northern Hemisphere (Mann et al., 2009). At Lake Pavin, such conditions have prevailed from AD 1300 to AD 1850 (Schettler et al., 2007) and, in addition to human disturbances affecting the vegetation cover, may promote soil erosion and runoff within the catchment. The Holocene climate variability is also dependent on the Total Solar Irradiance (TSI), characterized by millennial to decadal cycles (Steinhilber et al., 2009). It results in a succession of several solar minima that have been defined by cold intervals in Europe for the last millennium (Delaygue and Bard, 2011). Solar control; however, is not obvious in the Lake Pavin erosion record since it only matches the Maunder and Dalton minima (Fig. 8).

\subsubsection{The mid to late Holocene.}


From the mid to late Holocene, several phases of elevated terrigenous inputs can be depicted in the Lake Pavin erosion record (Fig. 9). Main minerogenic inputs (Ti flux) occurred at 6.9-6.5, 6.4, 6.1, 5.5, 4.0-3.9 cal kyr BP and during the LIA. The magnitude of Ti flux around 4 cal kyr BP and during the LIA is similar to the Ti flux occurring at the early stage of Lake Pavin. Accordingly, this proxy reflects erosion over an open or partially wooded catchment following episodes of anthropogenic wood clearance and/or local grazing activities. In addition, main organic input (rAP flux) is recorded at 5.8, 4.1-3.8, 3.5, 2.8-2.6, 1.8-1.6 cal kyr BP and during the LIA. The erosion phases documented around 4 cal kyr BP and during the LIA are also coeval with the occurrence of floods in the sedimentary record of Lake Aydat (Lavrieux et al., 2013), with enhanced terrigenous inputs from the sedimentary record of Lake Le Bourget (Arnaud et al., 2012) and with higher lake-level phases in Europe (Magny, 2004, Magny et al., 2009, 2012) indicating larger scale forcing mechanisms.

Over the last 7,000 years, the presence of MWDs in lacustrine sequences made it difficult to compare sedimentary records. However, it can be noted that the Lake Pavin erosion record and the Ti record of Lake Aydat do not match, except during the abovementioned periods. The continuous and large human impact within the Lake Aydat catchment likely explains the differences between these records (Lavrieux et al., 2013). Yet, the Lake Pavin erosion record, specifically the rAP flux, is in phase with the paleohydrological record inferred from the Lake Le Bourget sediments (Arnaud et al., 2012) and with phases of high lake-levels in Western Europe (Magny, 2004). Glacier oscillations over the last 3000 years generally correspond to the periods of enhanced terrestrial supplies in Lake Pavin, especially the Göschener 1 (G1) and the LIA advance phases in the Mer de Glace record (Le Roy et al., 2015) and the Holocene reconstructions of glacier advances in the Central Alps (Ivy-Ochs et al., 2009). Such similarities between the records indicate a connection between precipitation regimes over Lake Pavin and large scale climatic factors affecting Western Europe. 
Previous studies have demonstrated the existence of a mid-Holocene shift toward wetter and colder climatic conditions marking the onset of the Neoglacial era (Magny and Haas, 2004, Wanner et al., 2008). This was accompanied by a long-term cooling for the Late Holocene, with general glacier development and enhanced soil erosion in alpine environments (Ivy-Ochs et al., 2009, Simonneau et al., 2014). Closer to Lake Pavin, a similar scenario, with the onset of a more humid climate at $5.3 \mathrm{cal} \mathrm{kyr} \mathrm{BP}$, has also been inferred from the sedimentological record of the Sarliève paleolake near Clermont-Ferrand (Fig. 1A) (Fourmont et al., 2009, Macaire et al., 2010). This mid-Holocene transition is the result of the long-term orbital changes in seasonality, with a gradual decrease of summer insolation throughout the last 10,000 years (Berger and Loutre, 1991). According to Debret et al. (2009), the Holocene Thermal Maximum (HTM) was mainly induced by dominant solar forcing patterns that may enhance melt water in the Arctic Ocean from ice sheet retreats, leading to a weakening in the Atlantic Ocean circulation and thus, to a progressive decline in SST (Moros et al., 2004). The following reorganization of oceanic and atmospheric circulation patterns in the North Atlantic Ocean initiated the Neoglacial era under a predominant oceanic forcing (Mayewski et al., 2004, Debret et al., 2009). This new climate driver promoted enhanced westerlies in the North Atlantic atmospheric circulation. According to Wirth et al. (2013), an increase in flooding activity in the Southern Alps indicates a more negative NAO state during the second half of the Holocene, along with noticeable worldwide cooling events at 2.5, 1.6 and 0.6 cal kyr BP (Wanner et al., 2011). At Lake Pavin, matching between the rAP flux and the negative NAO phases (Fig. 9) provides evidence for the long-term Atlantic control on erosion processes. Thus, a coupling between the Atlantic Ocean and the atmosphere plays a fundamental role on the regional climate over Lake Pavin. In addition, the matching of some other detrital phases at $6.1,5.8,5.5,2.8-2.6$ and $0.5-0.3 \mathrm{cal} \mathrm{kyr} \mathrm{BP}$ with lower $\Delta \mathrm{TSI}$ values provides evidence of a solar influence (van Geel et al., 1998, Steinhilber et al., 2009). Nonetheless, deciphering the 
influence of oceanic vs. solar forcing on the Lake Pavin erosion record remains difficult without wavelet analysis.

\section{Conclusions}

The multi-proxy analysis of the core PAV12 sedimentary sequence documents the environmental and limnological evolution of Lake Pavin since its formation ca. 7000 years ago. Three main lithological units describe its evolution from a young mineral crater lake to an organic-rich ecosystem where sedimentation is mainly dominated by autochthonous production. Both organic and mineral signals highlight major limnological changes after the occurrence of: (1) a detrital event at 4.1-3.8 cal kyr BP; and (2) subaquatic slide(s) in AD 600 and/or $\mathrm{AD} 1300$. The later suggests that the current limnology might have prevailed for the past 700 years.

The Lake Pavin record also documents several phases of enhanced terrigenous fluxes highlighted by peaks of minerogenic (Ti) and/or organic (rAP) markers at ca. 6.5-5.5, 4.1-3.8, 3.5, 2.8-2.6, 1.6-1.4 cal kyr BP and during the LIA. A joint influence of climate and human activity on the Lake Pavin erosion record has been demonstrated. Apart from other regional records, palynological data here suggest a moderate human impact, limited to slight episodes of forest clearance and/or agropastoral activities. Consequently, the Lake Pavin erosion record appears primarily related to hydroclimatic fluctuations. The matching of enhanced terrigenous inputs with NAO negative phases and low TSI values supports both Atlantic and solar forcing at a centennial to millennial scale over the Holocene. On the other hand, human impacts, even at a low magnitude, cannot be ignored because of the specific configuration of the lake's catchment, where steep slopes may have augmented erosion processes driven by human disturbances during the ca. 4 cal kyr BP event and the LIA.

\section{Acknowledgments}


This work was carried out thanks to the financial support of CNRS-INSU in the framework of the DICENTIM project managed by Anne-Catherine Lehours. Léo Chassiot received a PhD grant from the Region Centre. We would like to thank the EDYTEM (CNRSUniversity of Savoie-Mont Blanc, France) laboratory for the XRF core scanner analyses, the IRAMAT (CNRS-University of Orleans, France) laboratory for LA-ICP-MS analyses and the ARTEMIS program for radiocarbon dating. The authors are also grateful to Didier Jézéquel for scientific discussions and to Kristen Conrad and Angus Ian Calderhead for English and linguistic corrections. Finally, we would like to thank Editor Paul Hesse, Jean-Nicolas Haas and an anonymous reviewer for their constructive remarks that substantially improved this manuscript. 


\section{References}

Aeschbach-Hertig, W., Hofer, M., Kipfer, R., Imboden, D.M., Wieler, R., 1999. Accumulation of mantle gases in a permanently stratified volcanic Lake (Lac Pavin, France). Geochimica et Cosmochimica Acta 63, 3357-3372.

Aeschbach-Hertig, W., Hofer, M., Schmid, M., Kipfer, R., Imboden, D.M., 2002. The physical structure and dynamics of a deep, meromictic crater lake (Lac Pavin, France). Hydrobiologia 487, 111-136.

Albéric, P., Jézéquel, D., Bergonzini, L., Chapron, E., Viollier, E., Massault, M., Michard, G., 2013. Carbon cycling and organic radiocarbon reservoir effect in a meromictic crater lake (lac Pavin, Puy-De-Dôme, France). Radiocarbon 55, 1029-1042.

Alexander, M.A., Halimeda Kilbourne, K., Nye, J.A., 2014. Climate variability during warm and cold phases of the Atlantic Multidecadal Oscillation (AMO) 1871-2008. Journal of Marine Systems 133, 14-26.

Antonetti, P., Brugel, E., Kessler, F., Barbe, J.-P., Tort, M., 2006. Atlas de la flore d'Auvergne. Conservatoire botanique national du Massif Central, 984 pp.

Ariztegui, D., Chondrogianni, C., Lami, A., Guilizzoni, P., Lafargue, E., 2001. Lacustrine organic matter and the Holocene paleoenvironmental record of Lake Albano (central Italy). Journal of Paleolimnology 26, 283-292.

Arnaud, F., Révillon, S., Debret, M., Revel, M., Chapron, E., Jacob, J., Giguet-Covex, C., Poulenard, J., Magny, M., 2012. Lake Bourget regional erosion patterns reconstruction reveals Holocene NW European Alps soil evolution and paleohydrology. Quaternary Science Reviews 51, 81-92. 
Assayag, N., Jézéquel, D., Ader, M., Viollier, E., Michard, G., Prévot, F., Agrinier, P., 2008. Hydrological budget, carbon sources and biogeochemical processes in Lac Pavin (France): Constraints from $\delta 180$ of water and $\delta 13 \mathrm{C}$ of dissolved inorganic carbon. Applied Geochemistry 23, 2800-2816.

Baker, A.G., Bhagwat, S.A., Willis, K.J., 2013. Do dung fungal spores make a good proxy for past distribution of large herbivores? Quaternary Science Reviews 62, 21-31.

Bhattacharya, T., Byrne, R., Böhnel, H., Wogau, K., Kienel, U., Ingram, B.L., Zimmerman, S., 2015. Cultural implications of late Holocene climate change in the Cuenca Oriental, Mexico. Proceedings of the National Academy of Sciences 112, 1693-1698.

Behar, F., Beaumont, V., Penteado, H.D.B., 2001. Rock-Eval 6 technology: performances and developments. Oil \& Gas Science and Technology 56, 111-134.

Behre, K.-E., 1981. The interpretation of anthropogenic indicators in pollen diagrams. Pollens et spores $23,225-245$.

Beniston M., Stoffel, M., 2016. Rain-on-snow events, floods and climate change in the Alps: Events may increase with warming up to $4^{\circ} \mathrm{C}$ and decrease thereafter. Science of the Total Environment 571, 228-236.

Berger, A., Loutre, M.F., 1991. Insolation values for the climate of the last 10 million years. Quaternary Science Reviews 10, 297-317.

Blaauw, M., Christen, J. A. 2011. Flexible paleoclimate age-depth models using an autoregressive Gamma Process. Bayesian Analysis 6, 457-474. 
Bonhomme, C., Poulin, M., Vinçon-Leite, B., Saad, M., Groleau, A., Jézéquel, D., Tassin, B., 2011. Maintaining meromixis in Lake Pavin (Auvergne, France): The key role of a sublacustrine spring. Comptes Rendus Géosciences 343, 749-759.

Brauer, A., Endres, C., Günter, C., Litt, T., Stebich, M., Negendank, J.F., 1999. High resolution sediment and vegetation responses to Younger Dryas climate change in varved lake sediments from Meerfelder Maar, Germany. Quaternary Science Reviews 18, 321-329.

Brisset, E., Miramont, C., Guiter, F., Anthony, E., Tachikawa, K., Poulenard, J., Arnaud, F., Delhon, C., Meunier, J.-D., Bard, E., Sumera, F., 2013. Non-reversible geosystem destabilisation at $4200 \mathrm{cal}$ BP: sedimentological, geochemical and botanical markers of soil erosion recorded in a Mediterranean alpine lake. The Holocene 23, 18631874.

Büntgen, Ü, Franck, D.C., Nievergelt, D., Esper, J., 2006. Summer Temperature Variations in the European Alps, A.D. 755-2004. Journal of Climate 19, 5606-5623.

Bura-Nakic, E., Viollier, E., Jézéquel, D., Thiam, A., Ciglenecki, I., 2009. Reduced sulfur and iron species in anoxic water column of meromictic maar Lake Pavin (Massif Central, France). Chemical Geology 266, 311-317.

Busigny, V., Jézéquel, D., Cosmidis, J., Viollier, E., Benzerara, K., Planavsky, N.J., Albéric, P., Lebeau, O., Sarazin, G., Michard, G., 2016. The Iron-Wheel in Lac Pavin: Interaction with phosphorus cycle, in Sime-Ngando, T., Boivin, P., Chapron, E., Jezequel, J., Meybeck, M. (Eds.): Lake Pavin, history, geology, biogeochemistry and sedimentology of a deep meromictic maar lake. Springer Cham, pp. 205-220. 
Busigny, V., Planavsky, N.J., Jézéquel, D., Crowe, S., Louvat, P., Moureau, J., Viollier, E., Lyons, T.W., 2014. Iron isotopes in an Archean ocean analogue. Geochimica et Cosmochimica Acta 133, 443-462.

Chapron, E., Albéric, P., Jézéquel, D., Versteeg, W., Bourdier, J.-L., Sitbon, J., 2010. Multidisciplinary characterization of sedimentary processes in a recent maar lake (Lake Pavin, French Massif Central) and implication for natural hazards. Natural Hazards and Earth System Science 10, 1815-1827.

Chapron, E., Ledoux, G., Simonneau, A., Albéric, P., St-Onge, G., Lajeunesse, P., Boivin, P., Desmet, M., 2012. New Evidence of Holocene Mass Wasting Events in Recent Volcanic Lakes from the French Massif Central (Lakes Pavin, Montcineyre and Chauvet) and Implications for Natural Hazards, in: Yamada, Y., Kawamura, K., Ikehara, K., Ogawa, Y., Urgeles, R., Mosher, D., Chaytor, J., Strasser, M. (Eds.), Submarine Mass Movements and Their Consequences. Springer Netherlands, Dordrecht, pp. 255-264.

Chassiot, L., Chapron, E., Di Giovanni, C., Albéric, P., Lajeunesse, P., Lehours, A.-C., Meybeck, M., 2016b. Extreme events in the sedimentary record of maar Lake Pavin: implication for natural hazards assessment in the French Massif Central. Quaternary Science Reviews 141, 9-25.

Chassiot, L., Chapron, E., Di Giovanni, C., Tachikawa, K., Garcia, M., Bard, E. 2016c. Historical seismicity of the Mont Dore volcanic province (Auvergne, France) unraveled by a regional lacustrine investigation: new insights about lake sensitivity to earthquakes. Sedimentary Geology 339, 134-150.

Chassiot, L., Chapron, E., Miras, Y., Schwab, M., Albéric, P., Beauger, A., Develle, A.-L., Arnaud, F., Lajeunesse, P., Zocatelli, R., Bernard, S., Lehours, A.-C., Jézéquel, D., 
2016a. Lake Pavin paleolimnology and event stratigraphy, in: Sime-Ngando, T., Boivin, P., Chapron, E., Jézéquel, D., Meybeck, M., (Eds.), Lake Pavin: history, geology, biogeochemistry and sedimentology of a deep meromictic maar lake. Springer Cham, pp. 381-406.

Coûteau, M., 1984. Recherches pollenanalytiques au lac d'Issarlès (Ardèche, France): évolution de la végétation et fluctuations lacustres. Bulletin de la Société Royale Botanique de Belgique 117, 197-217.

Cosmidis, J., Benzerara, K., Morin, G., Busigny, V., Lebeau, O., Jézéquel, D., Noël, V., Dublet, G., Othmane, G., 2014. Biomineralization of iron-phosphates in the water column of Lake Pavin (Massif Central, France). Geochimica et Cosmochimica Acta $126,78-96$.

Croudace, I.W., Rothwell, R.G., 2015. Micro-XRF Studies of Sediment Cores: applications of a non-destructive tool for the environmental sciences. Developments in Paleoenvironmental Research 17. Springer Netherlands, Dordrecht, 656 pp.

Cugny, C., Mazier, F., and Galop, D., 2010. Modern and fossil non-pollen palynomorphs from the Basque mountains (western Pyrenees, France): the use of coprophilous fungi to reconstruct pastoral activity. Vegetation History and Archaeobotany 19391 408.

de Beaulieu, J.L., Reille M., Pons, A., 1982. Recherches pollenanalytiques sur l'histoire de la végétation de la bordure nord du Massif du Cantal (Massif central, France). Pollen et spores 24, 251-300. 
Debret, M., Sebag, D., Crosta, X., Massei, N., Petit, J.-R., Chapron, E., Bout-Roumazeilles, V., 2009. Evidence from wavelet analysis for a mid-Holocene transition in global climate forcing. Quaternary Science Reviews 28, 2675-2688.

Delaygue, G., Bard, E., 2011. An Antarctic view of Beryllium-10 and solar activity for the past millennium. Climate Dynamics 36, 2201-2218.

Di Giovanni, C., Disnar, J.-R., Bichet, V., Campy, M., 2000. Saisonnalité et effets de seuils de la sédimentation organique détritique en milieu lacustre; hétérochromie de l'enregistrement organique et des fluctuations climatiques (bassin de Chaillexon, Doubs, France). Bulletin de la Société Géologique de France 171, 533-544.

Di Giovanni, C., Disnar, J.-R., Bichet, V., Campy, M., Guillet, B., 1998. Geochemical characterization of soil organic matter and variability of a postglacial detrital organic supply (Chaillexon Lake, France). Earth surface processes and landforms 23, 10571069.

Disnar, J.-R., Guillet, B., Kéravis, D., Di-Giovanni, C., Sebag, D., 2003. Soil organic matter (SOM) characterization by Rock-Eval pyrolysis: scope and limitations. Organic Geochemistry 34, 327-343.

Ejarque A., Miras Y., Riera Mora S., 2011. Modern pollen and non-pollen palynomorph analogues of vegetation and highland grazing activities obtained from surface and dung datasets from the eastern Pyrenees. Review of Palaeobotany and Palynology $167,123-139$.

Faegri K., Iversen J., 1989. Textbook of Pollen Analysis. New York, John Wiley \& Sons, 328 pp. 
Fourmont, A., Macaire, J.-J., Bréhéret, J.-G., 2009. Contrasted Late Glacial and Holocene hydrology of Sarliève paleolake (France) from sediment geometry and detrital versus biochemical composition. Journal of Paleolimnology 41, 471-490.

Gal, F., Gadalia, A., Millot, R., 2015. Geochemical Study of a Crater Lake: Lake Pavin, France:A View through Li-O-H Isotopes. Procedia Earth and Planetary Science 13, 189-193.

Gay, I., Macaire, J.-J., 1999. Estimation des taux d'érosion chimique tardiglaciaires et holocènes par la méthode des bilans d'altération. Application au bassin du lac Chambon (Massif central, France). Comptes Rendus de l'Académie des Sciences $328,387-392$.

Gratuze, B., Blet-Lemarquand, M., Barrandon, J.-N., 2001. Mass spectrometry with laser sampling: a new tool to characterize archaeological materials. Journal of Radioanalytical and Nuclear Chemistry 247, 645-656.

Graz, Y., Di-Giovanni, C., Copard, Y., Laggoun-Défarge, F., Boussafir, M., Lallier-Vergès, E., Baillif, P., Perdereau, L., Simonneau, A., 2010. Quantitative palynofacies analysis as a new tool to study transfers of fossil organic matter in recent terrestrial environments. International Journal of Coal Geology 84, 49-62.

Guenet, P., Reille, M., 1988. Analyse pollinique du lac-tourbière de Chambedaze (MassifCentral, France) et datation de l'explosion des plus jeunes volcans d'Auvergne. Bulletin de 1'Association française pour l'étude du Quaternaire 25, 175-194.

Hammer, Ø., Harper, D.A.T., and Ryan, P.D., 2001. PAST. Paleontological statistics software package for education and data analysis. Palaeontologia Electronica 4, 1-9. 
Hillbrand, M., Hadorn, P., Cugny, C., Hasenfratz, A., Galop, D., Haas, J.N., 2012. The palaeoecological value of Diporotheca rhizophila ascospores (Diporothecaceae, Ascomycota) found in Holocene sediments from Lake Nussbaumersee, Switzerland. Review of Palaeobotany and Palynology 186, 62-68.

Ivy-Ochs, S., Kerschner, H., Maisch, M., Christl, M., Kubik, P.W., Schlüchter, C., 2009. Latest Pleistocene and Holocene glacier variations in the European Alps. Quaternary Science Reviews 28, 2137-2149.

Juggins, S., 1991. C2 Data Analysis Vs.1.7.7, University of Newcastle, Newcastle.

Juvigné, E., Bastin, B., Delibrias, G., Evin, J., Gewelt, M., Gilot, E., Streel, M., 1996. A comprehensive pollen- and tephra-based chronostratigraphic model for the Late Glacial and Holocene period in the French Massif Central. Quaternary International 34-36, 113-120.

Juvigné, E., Stach-Czerniak, A., 1998. Étude sédimentologique et palynologique des dépôts lacustres tardiglaciaires et holocènes du Gour de Tazenat (Massif Central, France). Quaternaire 9, 15-23.

Lavrieux, M., Disnar, J.-R., Chapron, E., Bréheret, J.-G., Jacob, J., Miras, Y., Reyss, J.-L., Andrieu-Ponel, V., Arnaud, F., 2013. 6700 yr sedimentary record of climatic and anthropogenic signals in Lake Aydat (French Massif Central). The Holocene 23, $1317-1328$.

Lê, S., Josse, J., Husson, F., 2008. FactoMineR: An R package for multivariate analysis. Journal of Statistical Software 25, 1-18. 
Lehours, A.-C., Bardot, C., Thenot, A., Debroas, D., Fonty, G., 2005. Anaerobic Microbial Communities in Lake Pavin, a Unique Meromictic Lake in France. Applied and Environmental Microbiology 71, 7389-7400.

Lehours, A.-C., Evans, P., Bardot, C., Joblin, K., Gerard, F., 2007. Phylogenetic Diversity of Archaea and Bacteria in the Anoxic Zone of a Meromictic Lake (Lake Pavin, France). Applied and Environmental Microbiology 73, 2016-2019.

Le Roy, M., Nicolussi, K., Deline, P., Astrade, L., Edouard, J.-L., Miramont, C., Arnaud, F., 2015. Calendar-dated glacier variations in the western European Alps during the Neoglacial: the Mer de Glace record, Mont Blanc massif. Quaternary Science Reviews 108, 1-22.

Löwemark, L., Chen, H.-F., Yang, T.-N., Kylander, M., Yu, E.-F., Hsu, Y.-W., Lee, T.-Q., Song, S.-R., Jarvis, S., 2011. Normalizing XRF-scanner data: A cautionary note on the interpretation of high-resolution records from organic-rich lakes. Journal of Asian Earth Sciences 40, 1250-1256.

Macaire, J.-J., Fourmont, A., Argant, J., Bréheret, J.-G., Hinschberger, F., Trément, F., 2010. Quantitative analysis of climate versus human impact on sediment yield since the Lateglacial: The Sarliève palaeolake catchment (France). The Holocene 20, 497-516.

Magny, M., 2004. Holocene climate variability as reflected by mid-European lake-level fluctuations and its probable impact on prehistoric human settlements. Quaternary International 113, 65-79.

Magny, M., Arnaud, F., Billaud, Y., Marguet A., 2012. Lake-level fluctuations at Lake Bourget (eastern France) around 4500-3500 cal a BP and their palaeoclimatic and archaeological implications. Journal of Quaternary Science 27, 494-502. 
Magny, M., Haas, J.N., 2004. A major widespread climatic change around 5300 cal yr BP at the time of the Alpine Iceman. Journal of Quaternary Science 19, 423-430.

Magny, M., Vannière, B., Zanchetta, G., Fouache, E., Touchais, G., Petrika, L., Coussot, C., Walter-Simonnet, A.-V., Arnaud, F., 2009. Possible complexity of the climatic event around 4300-3800 cal BP in the central and western Mediterranean. The Holocene $19,823-833$.

Mann, M.E., Zhang, Z., Rutherford, S., Bradley, R.S., Hughes, M.K., Shindell, D., Ammann, C., Faluvegi, G., Ni, F., 2009. Global Signatures and Dynamical Origins of the Little Ice Age and Medieval Climate Anomaly. Science 326, 1256-1260.

Marchetto, A., Ariztegui, D., Brauer, A., Lami, A., Mercuri, A.M., Sadori, L., Vigliotti, L., Wulf, S., Guilizzoni, P., 2015. Volcanic Lake Sediments as Sensitive Archives of Climate and Environmental Change, in: Rouwet, D., Christenson, B., Tassi, F., Vandemeulebrouck, J. (Eds.), Volcanic Lakes. Springer Berlin Heidelberg, pp. 379399.

Martin, J.-M., Meybeck, M., Nijampurkar, V.N., Somayajulu, B.L.K., $1992 .{ }^{210} \mathrm{~Pb},{ }^{226} \mathrm{Ra}$ and ${ }^{32} \mathrm{Si}$ in Pavin lake (Massif Central, France). Chemical Geology 94, 173-181.

Martin-Puertas, C., Brauer, A., Dulski, P., Brademann, B., 2012. Testing climate-proxy stationarity throughout the Holocene: an example from the varved sediments of Lake Meerfelder Maar (Germany). Quaternary Science Reviews 58, 56-65.

Mayewski, P.A., Rohling, E.E., Curt Stager, J., Karlén, W., Maasch, K.A., David Meeker, L., Meyerson, E.A., Gasse, F., van Kreveld, S., Holmgren, K., Lee-Thorp, J., Rosqvist, G., Rack, F., Staubwasser, M., Schneider, R.R., Steig, E.J., 2004. Holocene climate variability. Quaternary Research 62, 243-255. 
Meybeck, M., Martin, J.-M., Olive, P., 1975. Géochimie des eaux et des sédiments de quelques lacs volcaniques du Massif-Central. Verhandlungen des Internationalen Verein Limnologie 19, 1150-1164.

Michard, G., Viollier, E., Jézéquel, D., Sarazin, G., 1994. Geochemical study of a crater lake: Pavin Lake, France - Identification, location and quantification of the chemical reactions in the lake. Chemical Geology 115, 103-115.

Miras Y., 2009. L'étude des relations entre végétation et pluie pollinique actuelle sur le plateau de Millevaches (Limousin, France) : outil pour une meilleure caractérisation pollenanalytique des formes paysagères et des pratiques agrosylvopastorales. Revue des Sciences Naturelles d'Auvergne 73, 71-105.

Miras, Y., Beauger, A., Lavrieux, M., Berthon, V., Serieyssol, K., Andrieu-Ponel, V., Ledger, P.M., 2015. Tracking long-term human impacts on landscape, vegetal biodiversity and water quality in the Lake Aydat catchment (Auvergne, France) using pollen, non-pollen palynomorphs and diatom assemblages. Palaeogeography, Palaeoclimatology, Palaeoecology 424, 76-90.

Miras, Y., Laggoun-Défarge, F., Guenet, P., Richard, H., 2004. Multi-disciplinary approach to changes in agro-pastoral activities since the Sub-Boreal in the surroundings of the Narse d'Espinasse (Puy de Dôme, French Massif Central). Vegetation History and Archaeobotany 13, 91-103.

Moros, M., Emeis, K., Risebrobakken, B., Snowball, I., Kuijpers, A., McManus, J., Jansen, E., 2004. Sea surface temperatures and ice rafting in the Holocene North Atlantic: climate influences on northern Europe and Greenland. Quaternary Science Reviews $23,2113-2126$. 
Olive, P., Boulègue, J., 2004. Étude biogéochimique d'un lac méromictique : le lac Pavin, France. Géomorphologie : relief, processus, environnement 10, 305-316.

Ortega, P., Lehner, F., Swingedouw, D., Masson-Delmotte, V., Raible, C.C., Casado, M., Yiou, P., 2015. A model-tested North Atlantic Oscillation reconstruction for the past millennium. Nature 523, 71-74.

Reille, M., 1992. Pollen et spores d'Europe et d'Afrique du nord. Marseille. Aix-Marseille, CNRS éditions, 520 pp.

Reille, M., Pons, A., de Beaulieu, J.-L., 1985. Recherches pollenanalytiques sur l'histoire tardiglaciaire et holocène de la végétation du Cézallier, de la Planèze de Saint-Flour et de la Margeride (Massif Central, France). Pollen et spores 27, 209-270.

Reimer, P.J., Bard, E., Bayliss, A., Beck, J.W., Blackwell, P.G., Bronk Ramsey, C., Buck, C.E., Cheng, H., Edwards, R.L., Friedrich, M., others, 2013. IntCal13 and Marine13 radiocarbon age calibration curves 0-50,000 years cal BP. Radiocarbon 55, 18691887.

Schettler, G., Schwab, M.J., Stebich, M., 2007. A 700-year record of climate change based on geochemical and palynological data from varved sediments (Lac Pavin, France). Chemical Geology 240, 11-35.

Sebag, D., Copard, Y., Di-Giovanni, C., Durand, A., Laignel, B., Ogier, S., Lallier-Verges, E., 2006b. Palynofacies as useful tool to study origins and transfers of particulate organic matter in recent terrestrial environments: Synopsis and prospects. EarthScience Reviews 79, 241-259.

Sebag, D., Disnar, J.R., Guillet, B., Di Giovanni, C., Verrecchia, E.P., Durand, A., 2006a. Monitoring organic matter dynamics in soil profiles by "Rock-Eval pyrolysis": bulk 
characterization and quantification of degradation. European Journal of Soil Science $57,344-355$.

Sifeddine, A., Bertrand, P., Lallier-Vergès, E., Patience, A.J., 1996. Lacustrine organic fluxes and palaeoclimatic variations during the last $15 \mathrm{ka}$ : Lac du bouchet (Massif Central, France). Quaternary Science Reviews 15, 203-211.

Simonneau, A., Chapron, E., Garçon, M., Winiarski, T., Graz, Y., Chauvel, C., Debret, M., Motelica-Heino, M., Desmet, M., Di Giovanni, C., 2014. Tracking Holocene glacial and high-altitude alpine environments fluctuations from minerogenic and organic markers in proglacial lake sediments (Lake Blanc Huez, Western French Alps). Quaternary Science Reviews 89, 27-43.

Simonneau, A., Doyen, E., Chapron, E., Millet, L., Vannière, B., Di Giovanni, C., Bossard, N., Tachikawa, K., Bard, E., Albéric, P., Desmet, M., Roux, G., Lajeunesse, P., Berger, J.F., Arnaud, F., 2013. Holocene land-use evolution and associated soil erosion in the French Prealps inferred from Lake Paladru sediments and archaeological evidences. Journal of Archaeological Science 40, 1636-1645.

Stebich, M., Brüchmann, C., Kulbe, T., Negendank, J.F.W., 2005. Vegetation history, human impact and climate change during the last 700 years recorded in annually laminated sediments of Lac Pavin, France. Review of Palaeobotany and Palynology 133, 115 133.

Steinhilber, F., Beer, J., Fröhlich, C., 2009. Total solar irradiance during the Holocene. Geophysical Research Letters 36, L19704. 
Striewski, B., Shulmeister, J., Augustinus, P.C., Soderholm, J., 2013. Late Holocene climate variability from Lake Pupuke maar, Auckland, New Zealand. Quaternary Science Reviews 77, 46-54.

Sweeney, C.A., 2004. A key for the identification of stomata of the native conifers of Scandinavia. Review of Palaeobotany and Palynology 128, 281-290.

Tanasienko, A.A., Yakutina, O.P., Chumbaev, A.S., 2011. Effect of snow amount on runoff, soil loss and suspended sediment during periods of snowmelt in southern West Siberia. Catena 87, 45-51.

Thouveny, N., Creer, K.M., Blunk, I., 1990. Extension of the Lac du Bouchet palaeomagnetic record over the last 120,000 years. Earth and Planetary Science Letters 97, 140-161.

Tjallingii, R., Röhl, U., Kölling, M., Bickert, T., 2007. Influence of the water content on Xray fluorescence core-scanning measurements in soft marine sediments. Geochemistry, Geophysics, Geosystems 8, Q02004.

Tribovillard, N., Algeo, T., Lyons, T., Riboulleau, A., 2006. Trace metals as paleoredox and paleoproductivity proxies: an update. Chemical Geology 232, 12-32.

Truze, E., Kelts, K., 1993. Sedimentology and paleoenvironment from the maar lac du Bouchet for the last climatic sycle, 0-120,000 years (Massif Central, France), in: Negendank, J.F.W. and Zolitschka, B., Paleolimnology of European Maar Lakes. Lecture Notes in Earth Sciences 49, Springer Eds, pp. 237-275.

van Geel, B., Buurmanb, J., Brinkkemperb, O., Schelvisc, J., Aptrootd, A., van Reenena, G., and Hakbijla, T., 2003. Environmental reconstruction of a Roman Period settlement site in Uitgeest (The Netherlands), with special reference to coprophilous fungi. Journal of Archaeological Science 30, 873-883 
van Geel, B., van der Plicht, J., Kilian, M.R., Klaver, E.R., Kouwenberg, J.H.M., Renssen, H., Reynaud-Farrera, I. and Waterbolk, H.T., 1998. The sharp rise of $\Delta^{14} \mathrm{C}$ ca. $800 \mathrm{cal}$ BC: possible causes, related climatic teleconnections and the impact on human environments. Radiocarbone 40, 535-550.

Viollier, E., Jézéquel, D., Michard, G., Pèpe, M., Sarazin, G., Alberic, P., 1995. Geochemical study of a crater lake (Pavin Lake, France): Trace-element behaviour in the monimolimnion. Chemical Geology 125, 61-72.

Viollier, E., Michard, G., Jézéquel, D., Pèpe, M., Sarazin, G., 1997. Geochemical study of a crater lake: Lake Pavin, Puy de Dôme, France. Constraints afforded by the particulate matter distribution in the element cycling within the lake. Chemical Geology 142, 225-241.

Wanner, H., Beer, J., Bütikofer, J., Crowley, T.J., Cubasch, U., Flückiger, J., Goosse, H., Grosjean, M., Joos, F., Kaplan, J.O., Küttel, M., Müller, S.A., Prentice, I.C., Solomina, O., 246 Stocker, T.F., Tarasov, P., Wagner, M., Widmann, M., 2008. Midto Late Holocene climate change: an overview. Quaternary Science Reviews 27, $1791-1828$.

Wanner, H., Solomina, O., Grosjean, M., Ritz, S.P., Jetel, M., 2011. Structure and origin of Holocene cold events. Quaternary Science Reviews 30, 3109-3123.

Weltje, G.J., Tjallingii, R., 2008. Calibration of XRF core scanners for quantitative geochemical logging of sediment cores: Theory and application. Earth and Planetary Science Letters 274, 423-438. 
Wirth, S.B., Glur, L., Gilli, A., Anselmetti, F.S., 2013. Holocene flood frequency across the Central Alps - solar forcing and evidence for variations in North Atlantic atmospheric circulation. Quaternary Science Reviews 80, 112-128.

Zolitschka, B., Anselmetti, F., Ariztegui, D., Corbella, H., Francus, P., Lücke, A., Maidana, N.I., Ohlendorf, C., Schäbitz, F., Wastegård, S., 2013. Environment and climate of the last 51,000 years - new insights from the Potrok Aike maar lake Sediment Archive Drilling prOject (PASADO). Quaternary Science Reviews 71, 1-12.

Zolitschka, B., Francus, P., Ojala, A.E.K., Schimmelmann, A., 2015. Varves in lake sediments - a review. Quaternary Science Reviews 117, 1-41. 


\section{Tables and figures caption}

Fig. 1. (A) Digital elevation model of the Auvergne region (France) displaying the location of the lakes Pavin (P), Aydat (A) and Sarliève (S). The location of Lake Le Bourget (LB) is indicated on the map of France. (B) Schematic map of Pavin crater rim with location of soil samples along with position of core PAV08 on the plateau and cores PAV12, PAV09-B1 and FC01 in the deep waters of Lake Pavin. (C) Aerial photography (courtesy of Francis Cormon) illustrating the forested topographic catchment area $\left(0.36 \mathrm{~km}^{2}\right)$ of Lake Pavin $\left(0.44 \mathrm{~km}^{2}\right)$. Note this catchment includes the Montchal stratovolcano rising at 1,407 m a.s.1.

Fig. 2. Schematic drawing resuming the limnogeology of maar Lake Pavin. Sedimentary units develop on three environments: the littoral ( $0-26 \mathrm{~m}$ water depth), the plateau $(26-55 \mathrm{~m})$ and the deep anoxic basin (below $90 \mathrm{~m}$ water depth). The AD 600 crater rim break-out generated an abrupt 9 m lake-level drop associated to a Mass-Wasting Deposit (MWD) on the plateau whereas the AD 1300 earthquake favored the slope failure at the edge of the plateau and a slump inside the deep basin. Presently, Lake Pavin fills with precipitation, runoff waters from the streams on forested slopes and two subaquatic springs (45 and $90 \mathrm{~m}$ ). Its water budget is balanced by two outlets (aerial and subaquatic). The carbon cycle biogeochemical reactions are represented with the photosynthesis $(\mathrm{P})$, evidenced in the mixolimnion by the maximum content of dissolved oxygen at $10 \mathrm{~m}$ water depth, the oxidation of organic matter (OMO) at the water bodies boundary (55-60 $\mathrm{m}$ water depth), the methanogenesis (MET) and the anaerobic oxidation of methane (AMO) within the monimolimnion (anoxic waters here characterized by an iron-wheel process). Chemical profiles in the water column are taken from Assayag et al. (2008). 
Fig. 3. Synthetic lithology and chronology of core PAV12. Triangles indicate local finingupward sequences interpreted as turbidites (see Chassiot et al., 2016a for details). Age-depth models and associated sedimentation rates for the last 7,000 years are represented for both upper and lower diatomite units, according to an interpolation between calibrated ages performed on BACON software (Blaauw and Christen, 2011). Letters refer to Table 2 where more information is given about conventional radiocarbon ages of PAV12 and others chronological constrains. Red leaves indicate rejected samples.

Fig. 4. (A) Selected XRF signals along with LA-ICP-MS results for elements Ti, Si, Fe and As showing the mineral signature of basal (U1), lower (U2) and upper (U4) units. (B) PCA results illustrating the artifact created by oxidation of the core with the precipitation of iron and manganese in the upper unit (U4). Because they have been poorly measured, $\mathrm{Al}$ and $\mathrm{Si}$ are indicated with dashed lines. (C) Linear regression between LA-ICP-MS analyses of Ti content (\%) with XRF core scanning of Ti signal (peak area).

Fig. 5. (A) S2 vs. TOC plot. Green dots: soil samples collected under deciduous and coniferous forest (Fig. 1B). Squares: samples from the basal unit. Black diamonds: samples from the lower unit. Crosses: samples from the MWD. White diamonds: samples from the upper unit. (B) Internal Standard (STD) and organic microfossils observed under transmitted and reflected light. AOM: Amorphous Organic Matter; rAP: Red Amorphous Particle; LCF: Ligno-Cellulosic Fragment; MYC: Mycelium. POL: pollen. Black bars correspond to a $50 \mu \mathrm{m}$ scale. 
Fig. 6. (A) Percentage pollen, spore and non-pollen palynomorphs diagram displaying selected taxa (exaggeration curve $\mathrm{x} 5$ ) for the PAV12 sequence. (B) Biostratigraphic zonation of the pollen diagram.

Fig. 7. Multi-proxy characterization of lower (I and II) and upper (III) units for the last 7,000 years. Enhanced mineral inputs underlined by the Ti content are indicated by grey bars that generally match higher soil markers (rAP) content in the organic fraction (see text for details). Leave symbols represent radiocarbon dates performed on core PAV12. Cf: Coprophilous fungi; API: Anthropogenic Pollen Indicators; MW: Mountain Woodland; DOW: Diversified Oak Woodland; LCF: Ligno-Cellulosic Fragments; rAP: red Amorphous Particles; AOM: Amorphous Organic Matter.

Fig. 8. Comparison of the Lake Pavin erosion record $(a, b)$ over the last 700 years with paleoenvironmental and paleoclimatic data collected from: (c) Lavrieux et al., 2013 (flood thickness in cm (black bars) and 31-yr running mean floods number (purple curve) at Lake Aydat); (d) Delaygue and Bard, 2011 (TSI); (e) Mann et al., 2009 (AMO); and (f) Ortega et al., 2015 (NAO; 5-yr running mean). Oort (O), Wolf (W), Spörer (S), Maunder (M) and Dalton (D) correspond to solar minima. Vertical grey strips correspond to short-term periods displaying the highest Ti flux in core PAV12. 
Fig. 9. Comparison of the Lake Pavin erosion record (a, b) over the last 7,000 years with paleoenvironmental records from Western Europe and paleoclimatic data: (c) Lake Aydat in the French Massif Central (Fig. 1A) (Lavrieux et al., 2013); (d) Lake Le Bourget in the French Pre-Alps (Fig. 1A) (Arnaud et al., 2012); (e) High lake-level phases in Western Europe (Magny, 2004); Alpine glaciers advances inferred from (f) the Central Alps (Ivy-Ochs et al., 2009) and (g) the Mer de Glace (Le Roy et al., 2015); (h) Paleo-NAO inferred from the flooding activity in the Southern Alps (Wirth et al., 2013); (i) Global cold events (Wanner et al., 2011); (j) Total Solar Irradiance index (Steinhilber et al., 2009); (k) Insolation (Berger and Loutre, 1991). Blue and red bars illustrate the general reorganization of Holocene climate from a dominant solar forcing toward an oceanic forcing (Debret et al., 2009). Vertical strips indicate phases with an enhancement of organic (light red) and minerogenic (grey) terrigenous fluxes.

Table 1. Radiocarbon samples and calibrated ages for cores PAV12 and PAV09-B1 with other chronological information from previous studies.

* rejected samples (see Fig. 3); ${ }^{\text {a }}$ Schettler et al. (2007); ${ }^{b}$ Chapron et al. (2010)

Table 2. Main pollen and non-pollen palynomorphs gathered according to their ecological affinities.

${ }^{\mathrm{a}}$ Hugo de Vries; ${ }^{\mathrm{b}}$ Toulouse-Mirail. 


\begin{tabular}{|c|c|c|c|c|c|c|}
\hline $\begin{array}{l}\text { Reference } \\
\text { letter }\end{array}$ & Core & Depth $(\mathrm{cm})$ & $\begin{array}{l}\text { Laboratory } \\
\text { reference }\end{array}$ & Material & $\begin{array}{l}\text { Radiocarbon } \\
\text { age (yr BP) }\end{array}$ & $\begin{array}{l}2 \sigma \quad \text { (cal yr } \\
\text { BP) }\end{array}$ \\
\hline $\mathrm{A}^{*}$ & PAV12 & 81 & Beta-336274 & Leaf & $1190 \pm 30$ & $1120 \pm 65$ \\
\hline $\mathrm{B}^{*}$ & PAV09-B1 & 94.5 & SacA-19661 & Leaf & $440 \pm 35$ & $495 \pm 40$ \\
\hline $\mathrm{C}$ & PAV09-B1 & 96.5 & Poz-33126 & Leaf & $150 \pm 30$ & $200 \pm 35$ \\
\hline D* & PAV09-B1 & 113 & Poz-33125 & Leaf & $1010 \pm 30$ & $940 \pm 35$ \\
\hline $\mathrm{E}$ & PAV12 & 137 & Lyon-10961 & Leaf & $220 \pm 30$ & $285 \pm 20$ \\
\hline $\mathrm{F}^{\mathrm{a}}$ & FC01 & 206 & \multicolumn{4}{|c|}{ Calendar age from varve counting $=668 \mathrm{cal} \mathrm{yr} \mathrm{BP}$} \\
\hline $\mathrm{G}^{*}$ & PAV12 & $287-289$ & Beta-336272 & Leaf & $2210 \pm 30$ & $2235 \pm 85$ \\
\hline $\mathrm{H}$ & PAV12 & $645-646$ & SacA34984 & Leaf & $1730 \pm 30$ & $1635 \pm 70$ \\
\hline $\mathrm{I}$ & PAV12 & 701 & Lyon-10963 & Leaf & $2195 \pm 35$ & $2220 \pm 95$ \\
\hline $\mathrm{J}$ & PAV12 & 755 & Beta-336273 & Leaf & $2400 \pm 30$ & $2420 \pm 70$ \\
\hline $\mathrm{K}^{*}$ & PAV12 & 798 & SacA34983 & Leaf & $4170 \pm 30$ & $4690 \pm 90$ \\
\hline $\mathrm{L}$ & PAV12 & 827 & Beta-335372 & Leaf & $3400 \pm 30$ & $3640 \pm 70$ \\
\hline $\mathrm{M}$ & PAV12 & $880-881$ & Beta-335371 & Leaf & $3940 \pm 30$ & $4365 \pm 80$ \\
\hline $\mathrm{N}$ & PAV12 & 919 & Beta-335370 & Leaf & $4400 \pm 40$ & $4960 \pm 100$ \\
\hline $\mathrm{O}$ & PAV12 & 978.5 & Lyon-10962 & Leaf & $5250 \pm 35$ & $5980 \pm 55$ \\
\hline $\mathrm{P}^{\mathrm{b}}$ & PAV08 & $476-479$ & Poz-27052 & Bulk & $6090 \pm 40$ & $6940 \pm 90$ \\
\hline
\end{tabular}

Table 1 


\begin{tabular}{|c|c|}
\hline Groups & Pollen types \\
\hline Diversified Oak Woodland & Quercus, Tilia, Ulmus, Acer \\
\hline Mountain Woodland & Fagus, Abies \\
\hline Riparian Woodland & Alnus, Salix, Fraxinus, Populus \\
\hline Coniferous Woodland & Pinus, Juniperus \\
\hline Grasslands & Poaceae \\
\hline Agriculture & Cerealia-t, Secale-t, Fagopyrum \\
\hline $\begin{array}{l}\text { Anthropogenic Pollen } \\
\text { Indicators }\end{array}$ & $\begin{array}{l}\text {, Centaurea cyanus, Mercurialis annua- } t \text {, Urticaceae, } \\
\text { Polygonum persicaria-t (Persicaria maculosa- } t \text { ), Polygonum } \\
\text { aviculare- } t \text {, Galium, Artemisia, Rumex, Rumex acetosella-type, } \\
\text { Rumex acetosa-type, Chenopodiaceae, Cirsium-t, Plantago, } \\
\text { Plantago lanceolata-t, }\end{array}$ \\
\hline Groups & Non-Pollen Palynomorphs types \\
\hline Coprophilous fungi & $\begin{array}{l}\text { Sporormiella }\left(\mathrm{HdV}^{\mathrm{a}}-113\right), \text { Sordaria }(\mathrm{HdV}-55), \text { Coniochaeta } \mathrm{cf} \\
\text { ligniaria }(\mathrm{HdV}-172), \text { Coniochaeta } \mathrm{B}\left(\mathrm{TM}^{\mathrm{b}}-211\right), \text { Podospora } \\
(\mathrm{HdV}-368), \text { Delitschia }(\mathrm{TM}-023 \mathrm{~A} / \mathrm{B})\end{array}$ \\
\hline
\end{tabular}

Table 2 


\section{HIGHLIGHTS}

A 14 m core documents the 7,000-year environmental history of Lake Pavin.

A shift in redox elements supports a major limnological change induced by a MWD.

An erosion record was built from Red Amorphous Particles and Titanium.

Long-term fluctuations are driven by an Atlantic forcing during the Neoglacial. 


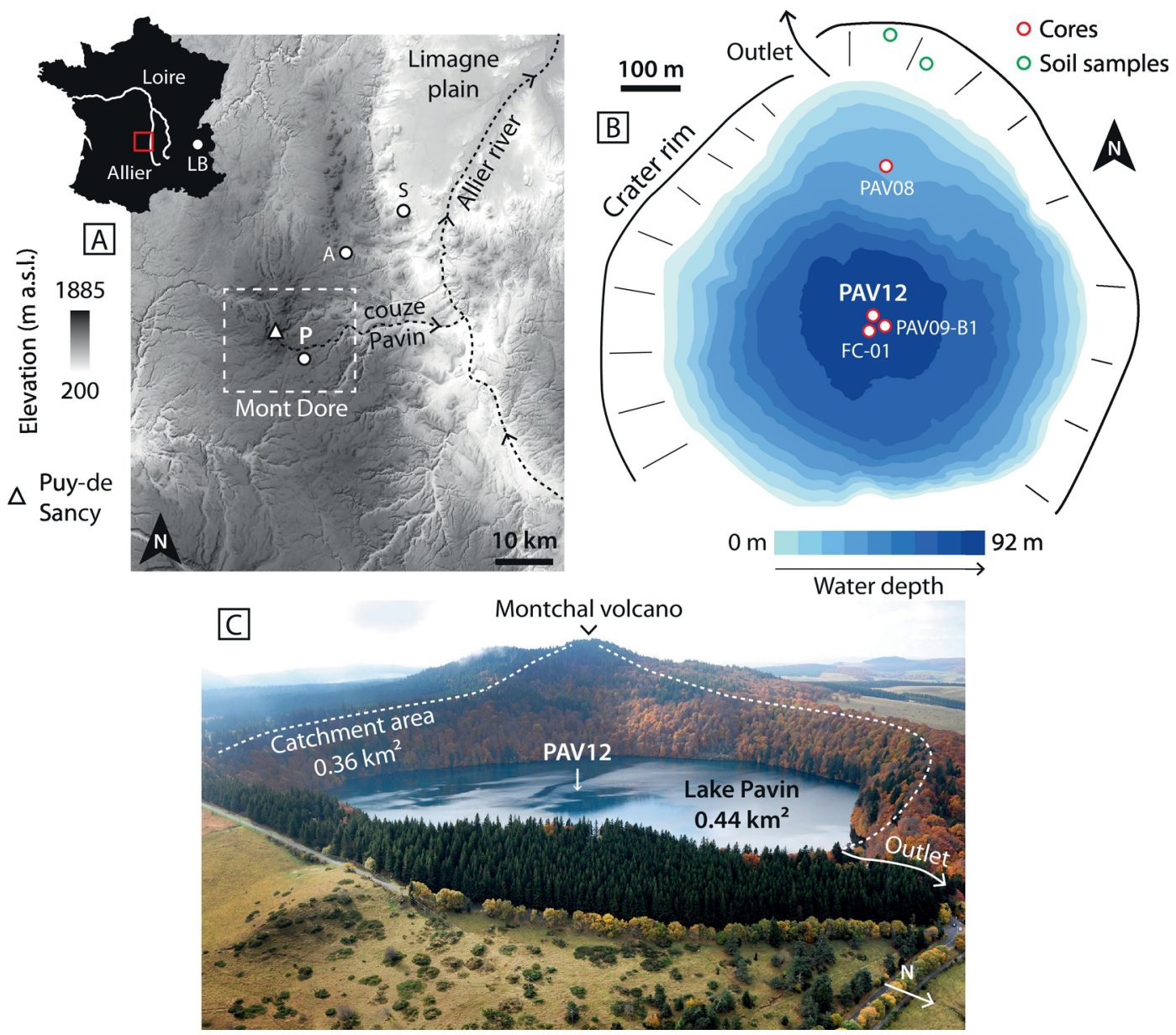

Figure 1 
Littoral unit

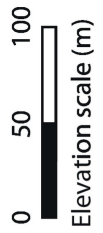

In-situ diatomite unit

AD 1300 MWD

AD 600 MWD

Former crater rim

Volcano-clastic material

\section{Crater rim break}

AD 600

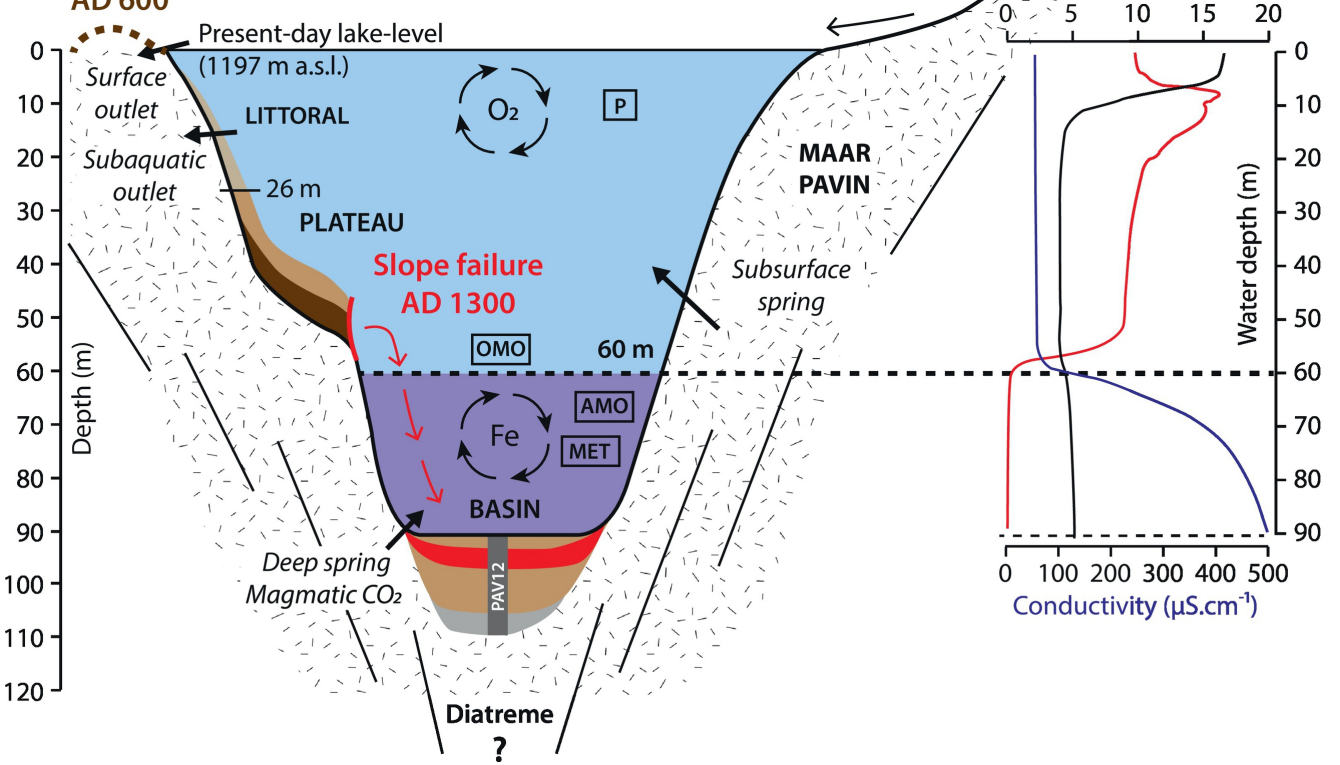

Figure 2

Oxic waters

Mixolimnion

Anoxic waters

Monimolimnion
Volcano height

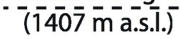

Precipitations

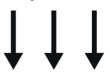

streams

Temp. $\left({ }^{\circ} \mathrm{C}\right)$

Runoff

Surface
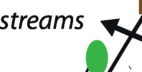
VOLCANO 
Age (kyrs cal BP)

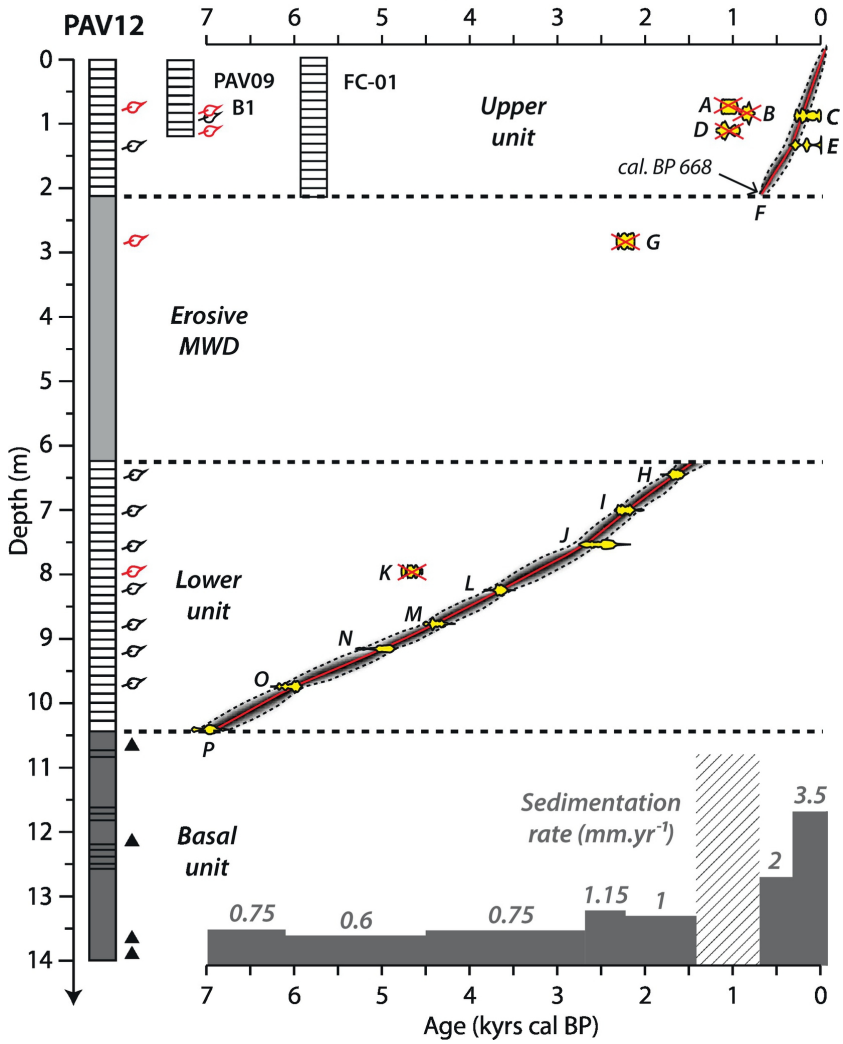

Figure 3 


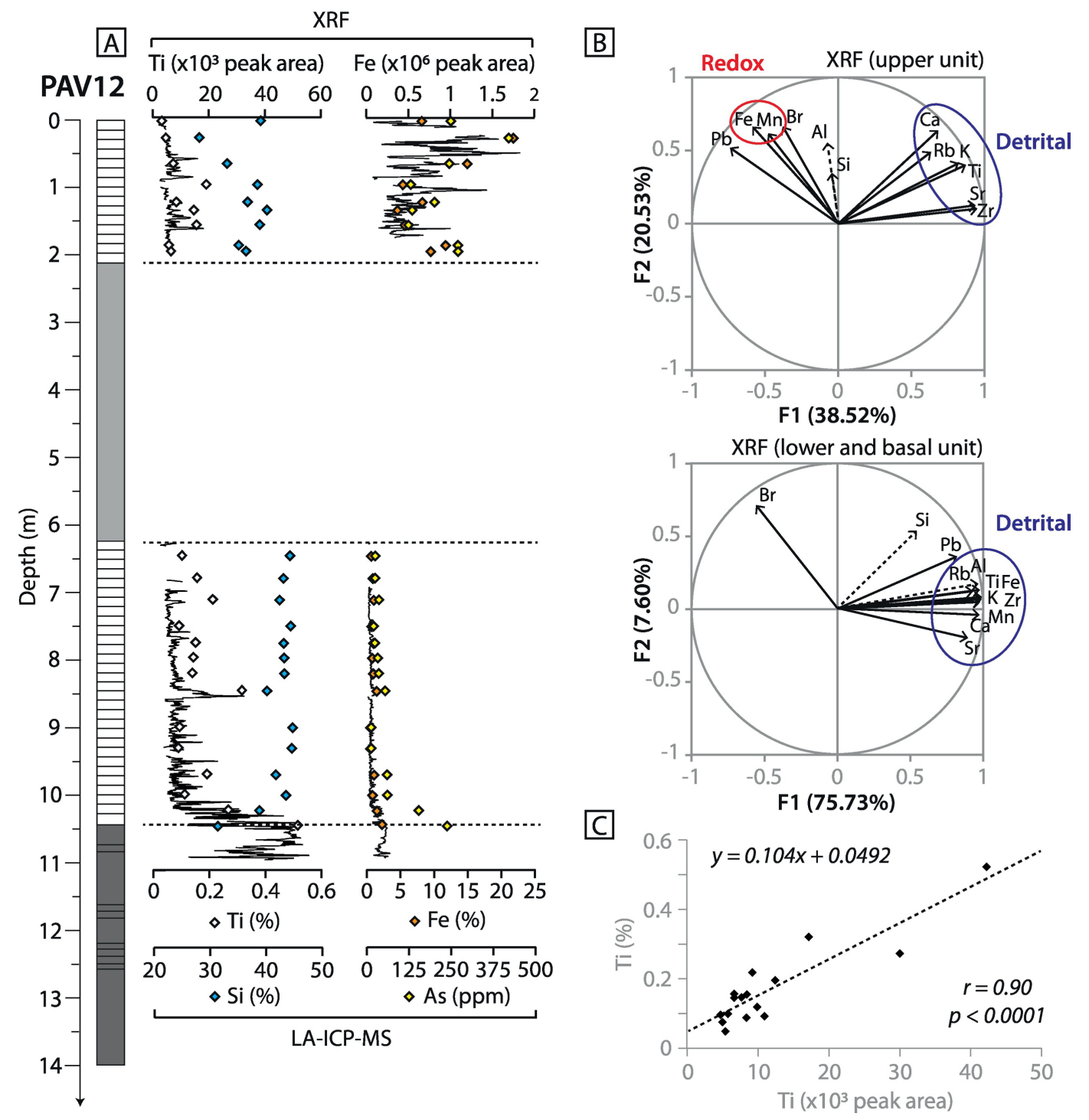




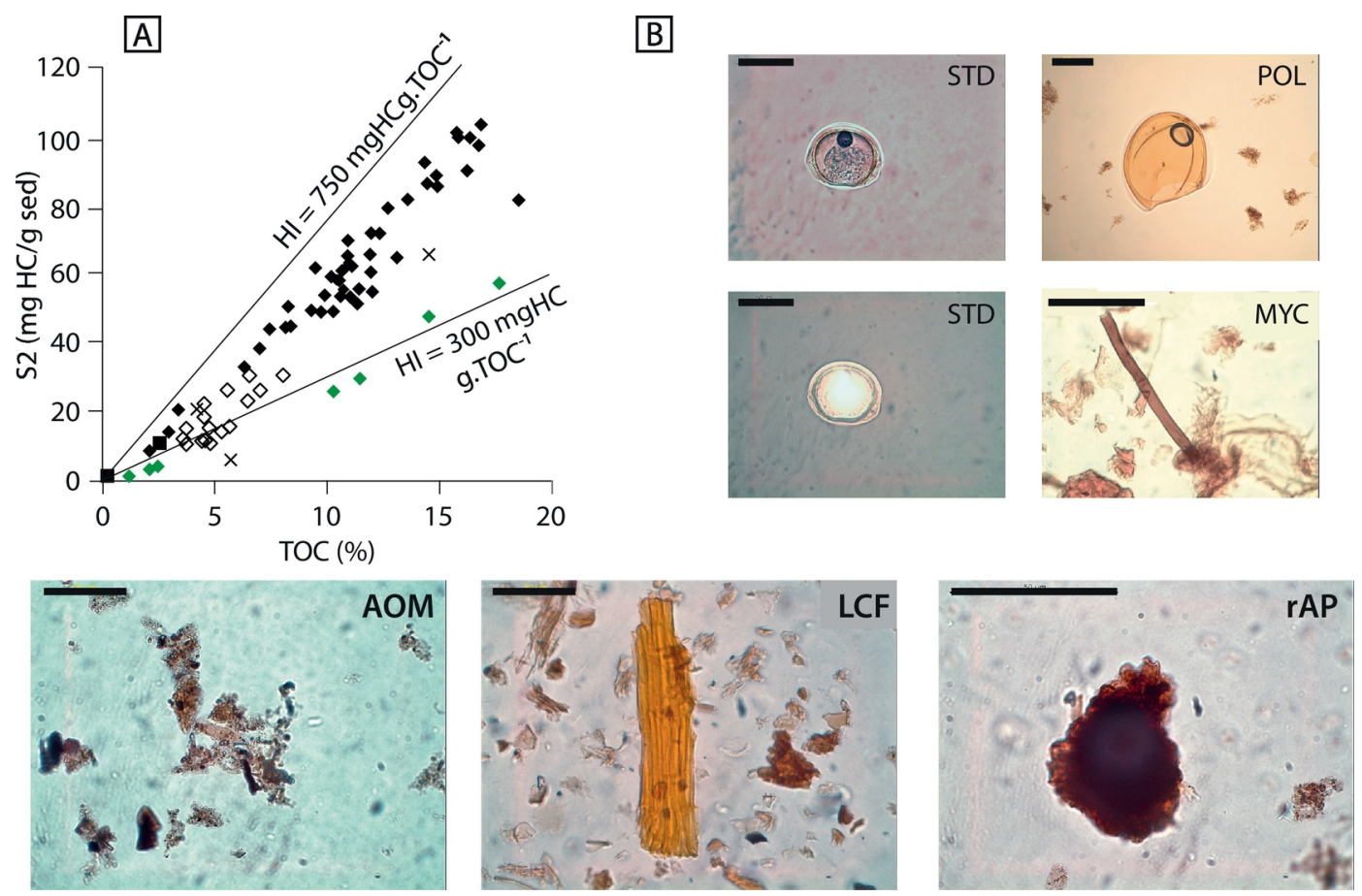

Figure 5 
A
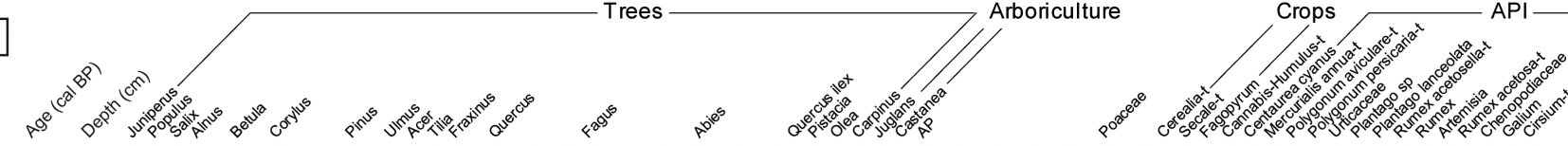

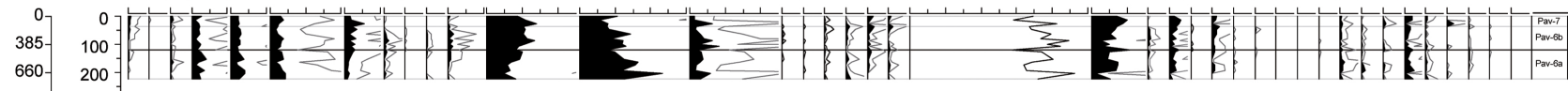
300 400 Mass-Wasting Deposit

2200

3300

4700

6300

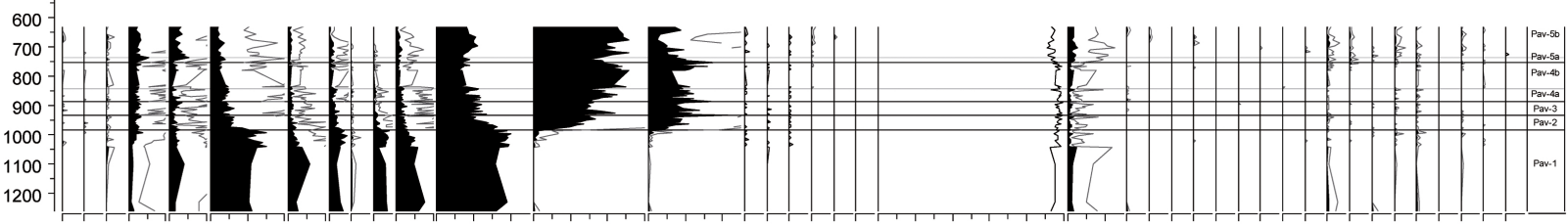

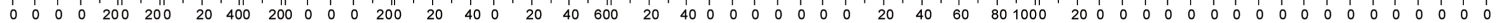
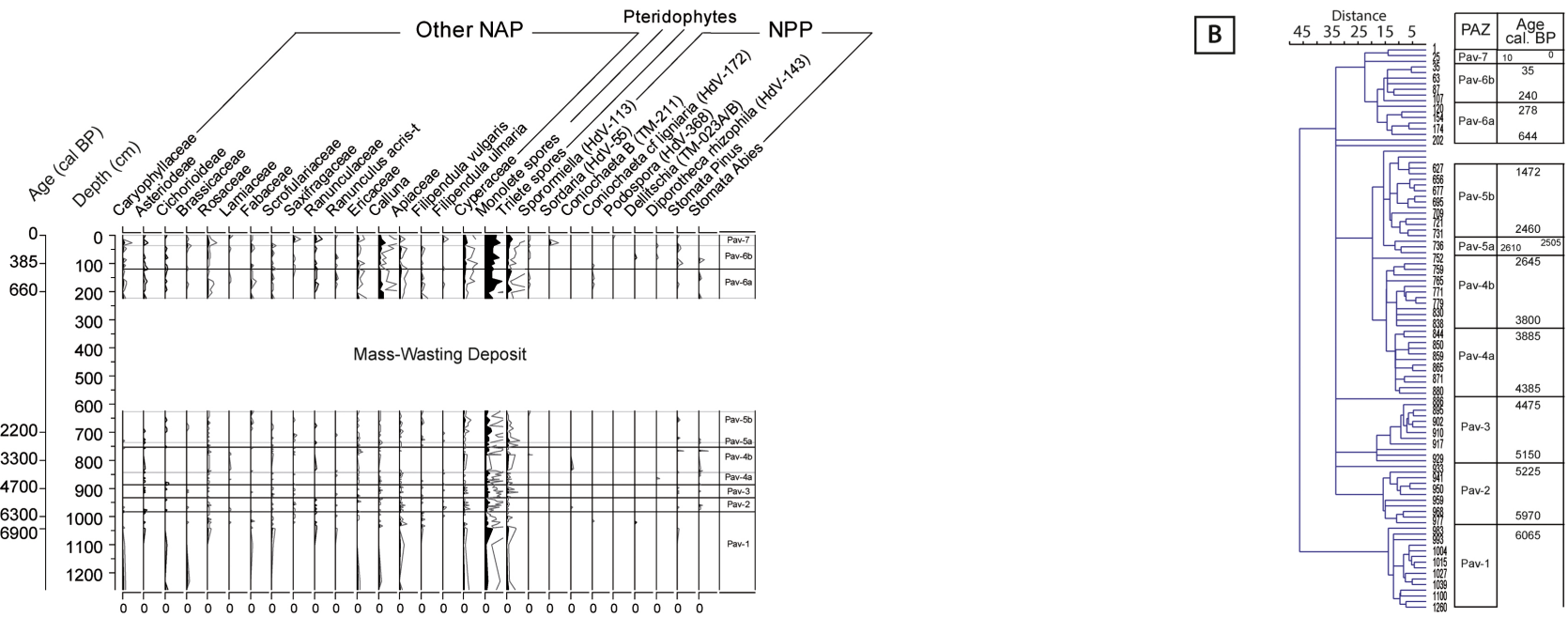

Figure 6 
Age (cal kyr BP)

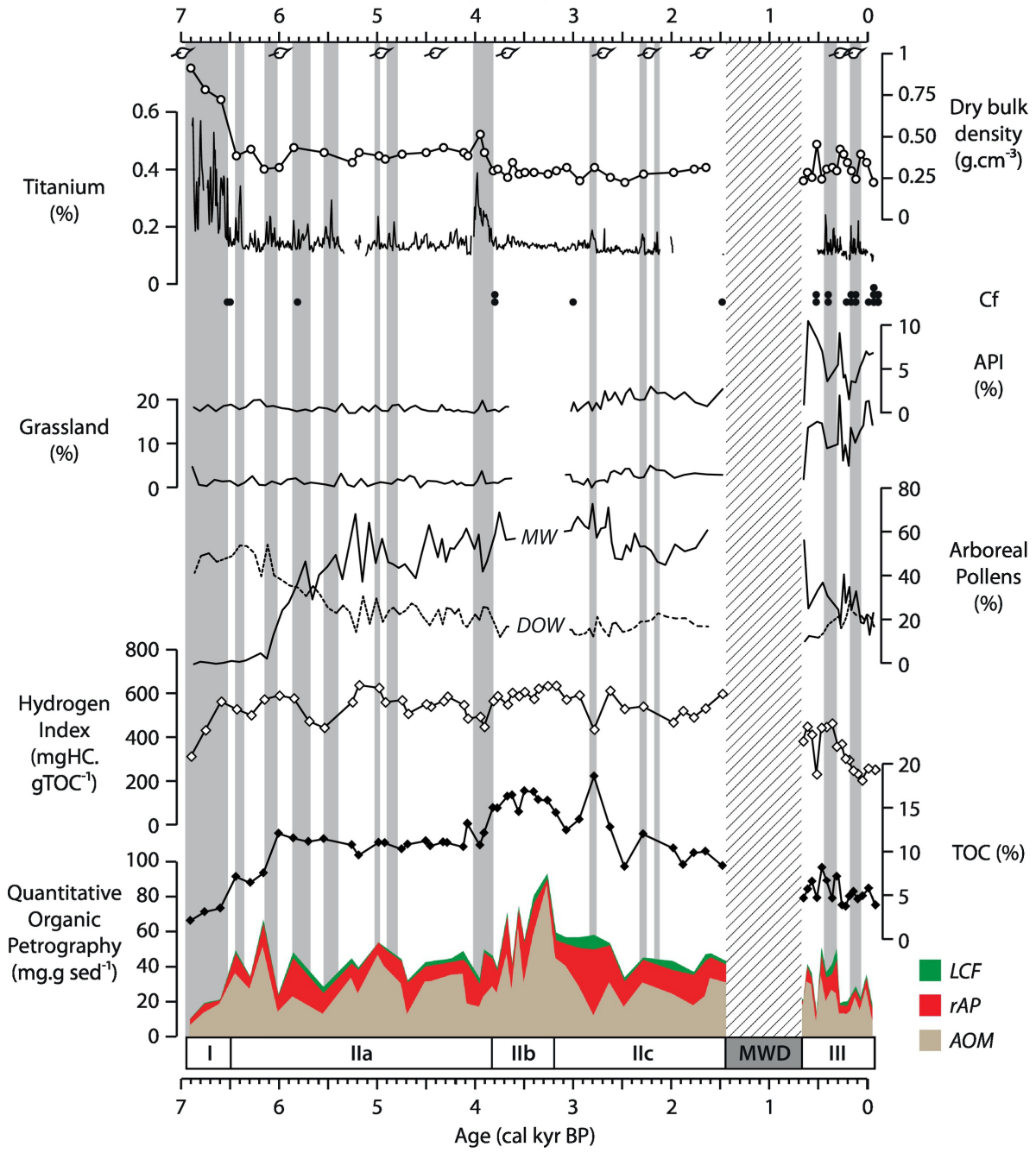

Figure 7 
Age (cal yr BP)

$\begin{array}{llllllllll}900 & 800 & 700 & 600 & 500 & 400 & 300 & 200 & 100 & 0\end{array}$

(f) NAO Index
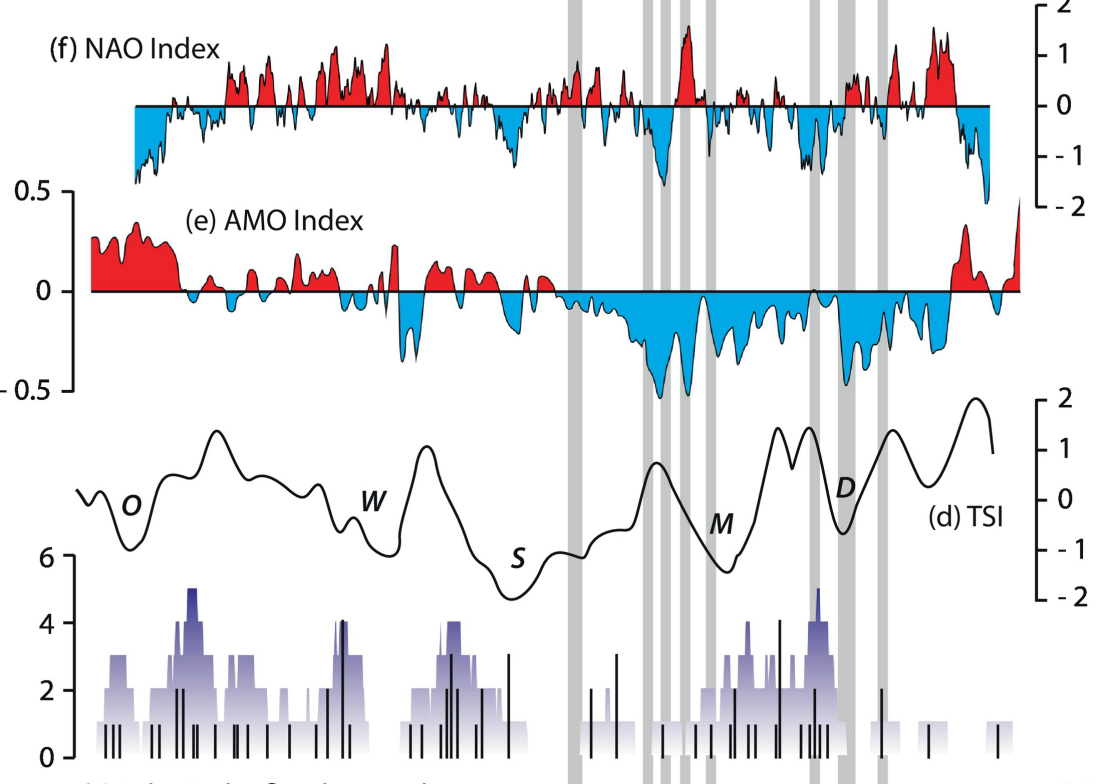

(c) Lake Aydat floods record

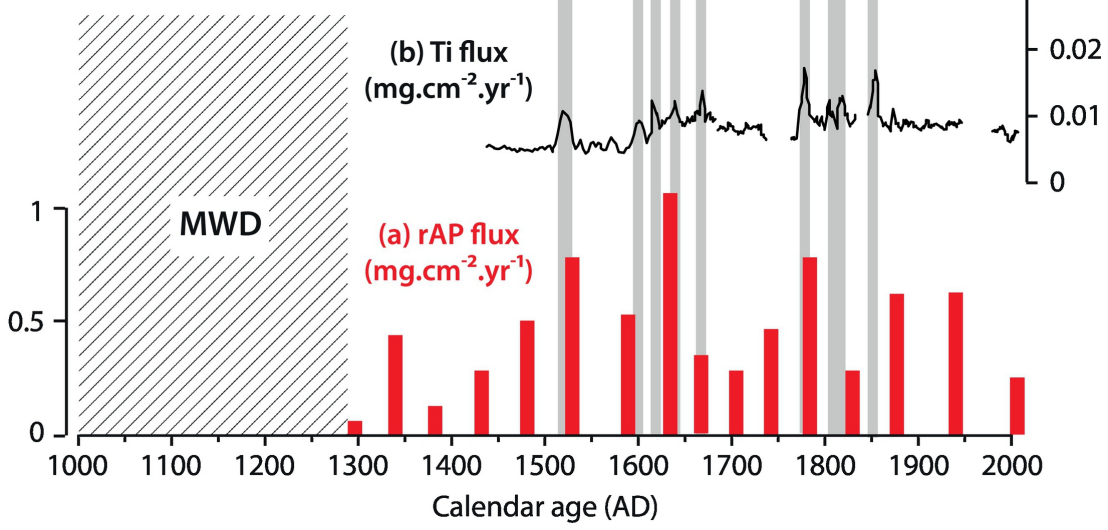




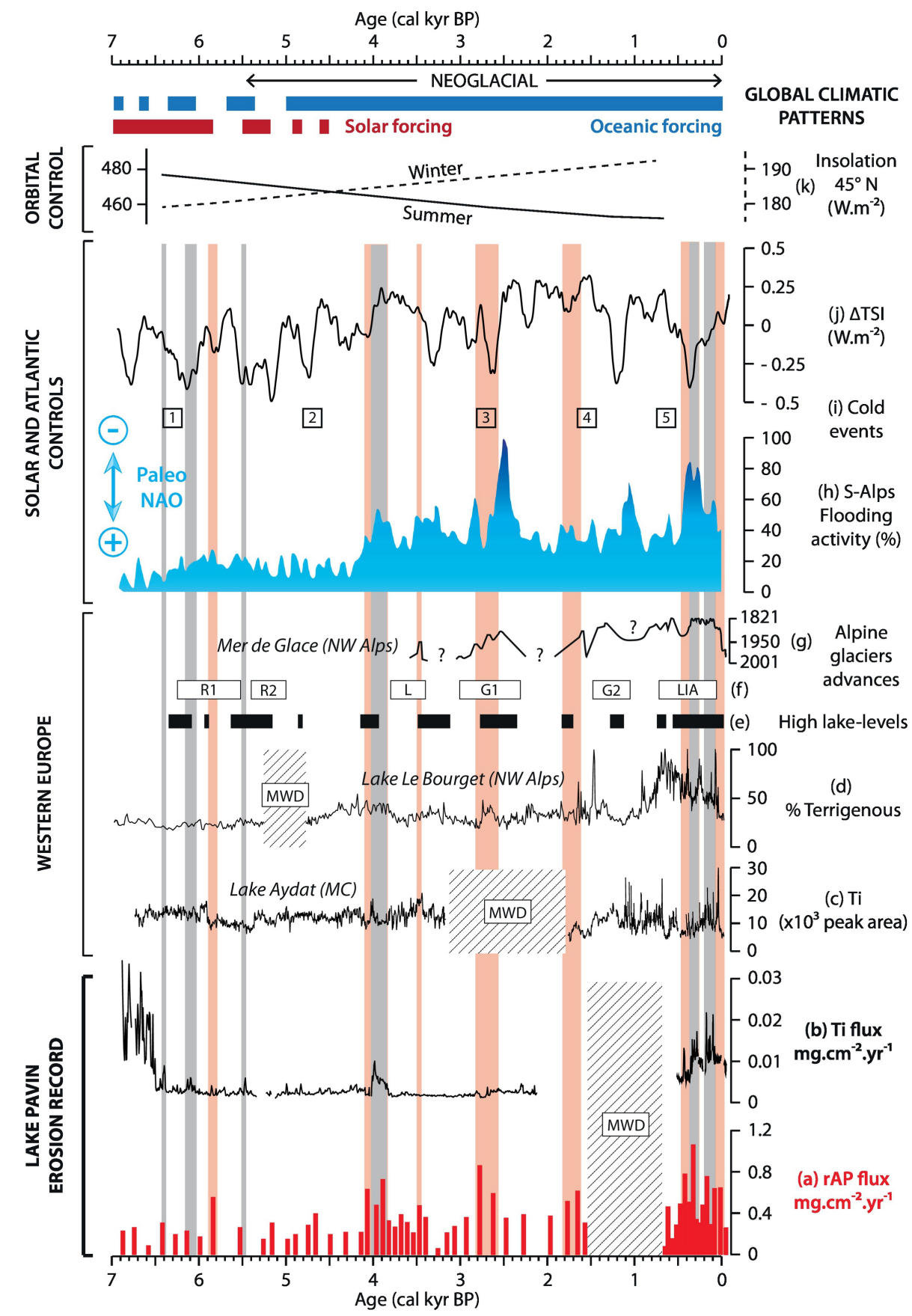

